TANNIER C., BOURGEOIS M., HOUOT H., FOLTÊTE J-C. (2016), Impact of urban developments on the functional connectivity of forested habitats: a joint contribution of advanced urban models and landscape graphs, Land Use Policy, vol. 52, pp. 76-91.

\title{
Impact of urban developments on the functional connectivity of forested habitats: a joint contribution of advanced urban models and landscape graphs
}

\author{
Cécile Tannier*, Marc Bourgeois*, Hélène Houot*, Jean-Christophe Foltête*
}

\footnotetext{
${ }^{*}$ Chrono-Environnement, French national Centre for Scientific Research - University of FrancheComté, Besançon, France

* ThéMA, French national Centre for Scientific Research - Universities of Franche-Comté and Burgundy, Besançon-Dijon, France
}

\begin{abstract}
The impacts of urban growth on biodiversity vary according to the form and the intensity of urbanisation. However, there is a lack of knowledge about the consequences of the type of urban structure (eg. monocentric vs polycentric), the shape of urban boundaries, the local density of residential development, on the habitats of wildlife species. In this context, this paper focuses on the relationship between forms of urbanisation and functional connectivity of ecological habitats. In the urban region of Besançon (eastern France), three emblematic protected species were selected to represent forest mammals. From the initial state describing current land cover, five prospective residential development scenarios were simulated, corresponding to the form currently most commonly found (e.g. compact development, transit-oriented development, polycentric development). For each scenario, we also simulate the volume of traffic on the road network to allow for the barrier effect of roads on habitat connectivity. Then, for each development scenario, we model the functional connectivity of habitats of the various target species using landscape graphs. Results show that compact city maintains more functional connectivity for all the species considered whereas urban sprawl leads to much more marked impacts. Moderately compact and regulated periurban scenarios have intermediate levels of impact. The transit-oriented development scenario produces specific impact values according to the species. An interesting point is that the decline in functional connectivity of forest habitats is more due to increased traffic than residential development proper. This outlines the relevance of integrated models for simulating both land use and transport at a fine scale.
\end{abstract}

Keywords: residential development, ecological habitat, ecological connectivity, computerbased simulation, landscape graphs 


\section{Introduction}

In many countries worldwide demand for housing is growing continually and necessitating the construction of new residential property. The resulting urban sprawl must be controlled so as to abate the social, economic and environmental nuisances arising from this. One of the major ecological impacts of urban growth is the decline in biodiversity. This decline stems mostly from the loss and fragmentation of species habitats ( Fahrig, 1997; Forman, 1995; Hanski, 2011), which are compounded by the barrier effect of urbanised zones (Marull and Mallarach, 2005) and transport networks (Forman and Alexander, 1998; Fu et al., 2010; Girardet et al., 2013). Such impacts on biodiversity vary with the form and intensity of urbanisation (Alberti, 2005).

Certain relationships have been observed between urban form and species habitat, especially animal species habitat. On the scale of an urban region, urban sprawl may entail increased traffic induced by daily trips between the centre(s) and the outskirts (Camagni et al., 2002; Mörtberg et al., 2007; Aguilera et al., 2011) and consequently a barrier effect of transport networks (Fu et al., 2010; Gurrutxaga et al., 2010). On a local scale, dense urban development may avert the loss of ecological habitats (Conway, 2009) but concomitantly increase the barrier effect of built areas (Marull and Mallarach, 2005; Aguilera et al., 2011). Conversely, loose urban development increases landscape fragmentation but the barrier effect of built areas may be reduced if the urban boundary remains comparatively fuzzy (Czamanski et al., 2008).

This knowledge must be extended, though, if planners are to able to tell where to open up new areas for urbanisation and which urban forms to promote in order to minimise impacts on species habitat functionality. The main questions are:

- On the scale of an entire urban region, for instance, under regional development plans, is it more relevant to species habitat functionality, to concentrate new urban developments in the main urban centre (monocentric development) or to share urban growth among several centres (polycentric development)? What shape should the urban boundary be: smooth (i.e. sharp) or frilled (i.e. fuzzy)?

- What shape should new residential developments be on the neighbourhood scale? Very dense or less dense?

An attempt to answer these questions can be made by using prospective analyses that involve comparing the potential impact of urbanisation scenarios according to several possible approaches. Some commentators simulate different natural habitat patterns and evaluate the potential impact of urbanisation on these natural habitats (Bierwagen, 2007). Others evaluate the ecological impacts of urbanisation scenarios supplied by the local authorities (Mörtberg et al., 2007; Scolozzi and Geneletti, 2012). Yet others simulate their own urbanisation scenarios by generating either stylised (Syphard et al., 2005; Mitsova et al., 2011; Tannier et al., 2012a), or more realistic (Beardsley et al., 2009; Aguilera et al., 2011) forms of urbanisation. Such simulated urbanisation scenarios are not predictions about future urbanisation but rather various possible developments of the city by which alternative planning schemes can be compared (Aguilera et al., 2011). 
The way in which the ecological impact of forms of urbanisation is measured also varies among commentators. Some measure the loss of habitat in ecologically sensitive zones (Mörtberg et al., 2007; Beardsley et al., 2009). Others measure the loss of structural connectivity (Syphard et al., 2005; Bierwagen, 2007; Mitsova et al., 2011). Others still measure the loss of functional connectivity (Mitsova et al., 2011; Tannier et al., 2012a). Our own preference goes to this last criterion because functional connectivity is a key factor in the movement of organisms both for the satisfaction of their day-to-day requirements within their home range and to ensure the mixing of populations and gene dissemination (Taylor et al., 2006). In evaluating functional connectivity, the landscape graph approach provides a suitable compromise between the quantity and precision of data required for the analysis and their capacity to represent ecological flows (Urban et al., 2009). Moreover, this form of modelling can be used for operational applications in the context of planning schemes (Zetterberg et al., 2010; Foltête et al., 2014).

For a given species, the impact of an urbanisation scenario is estimated by measuring the loss of functional connectivity of its habitat between the initial and final states of land use further to a simulated urbanisation process. However, given the diversity of needs of different animal species, it is an oversimplification to work on just one target species (Lindenmayer et al., 2000). The multi-species approach, i.e. considering a set of target species, is a good compromise between an empirical ecological representation and modelling. Various strategies are available through which to implement this approach. Some investigators use fictitious species (Tannier et al., 2012a) or actual species (Carroll et al., 2001). Others opt to represent groups of actual species by a fictitious species (Minor and Lookingbill, 2010; García-Feced et al., 2011).

In this paper, we attempt to further our knowledge of the relationship between forms of urbanisation and functional connectivity of ecological habitats. To do this, we take account of certain morphological and functional characteristics of both built and natural landscapes on various scales. The animal species under study are forest-dwelling mammals, subdivided into three groups according to the area of their home range and their dispersal distance. We take a two-stage approach.

First we simulate prospective residential development scenarios starting from a real initial state. In creating each scenario we vary those elements of urban form that may have a significant impact on the connectivity of forest mammal habitats. The urban forms simulated in this way are realistic on a local scale. On a broader scale, they correspond to the lines of development that are currently most commonly found (e.g. compact development, transitoriented development, polycentric development). For each scenario, we also simulate the volume of traffic on the road network to allow for the barrier effect of roads on habitat connectivity.

Second, for each development scenario, we model the functional connectivity of habitats of the various target species using landscape graphs. The entire approach is applied to a study case of the Besançon urban region (eastern France). 


\section{Material and methods}

\subsection{Study area}

The study area encompasses the city of Besançon (117 000 inhabitants) and its urban region (317 000 inhabitants). Within this area of $3600 \mathrm{~km}^{2}$, elevation rises from the plains of the north-west to the medium altitude mountains of the south-east (200-1000 m). Except for central Besançon, the population density is low at 57 inhabitants $/ \mathrm{km}^{2}$. Natural and agricultural environments are widespread with $48 \%$ forest, $25 \%$ grassland and $16 \%$ arable land. These environments are threatened by strong urbanisation in periurban areas (26.5\% population increase 1999-2008).

\subsection{Study species}

The landscape mosaic of the study area is formed mostly by woodland and farmland patches. Here we concentrate on forest mammals living in the woodland patches and using the farmland areas for hunting or movement. Ten forest mammal species found in the study area and threatened by urbanisation were identified using a regional naturalist data base (www.sigogne.org) and the IUCN Red List (IUCN, 2013). These species were subdivided into three groups (small, medium and large mammals) according to two main functional traits, the home range and the dispersal distance, by the method employed by Minor and Lookingbill (2010) (Figure 1). From the three groups, three emblematic protected species were selected: the Eurasian lynx (Lynx lynx), the wild cat (Felis silvestris) and the red squirrel (Sciurus vulgaris). Study of the three species represents all of the forest mammals threatened by urbanisation in the study area.

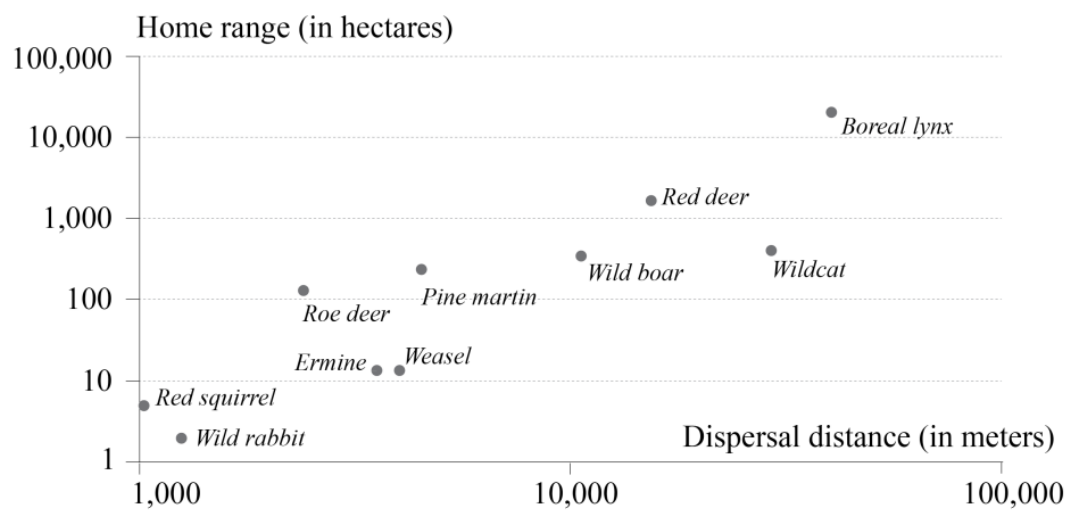

Figure 1. Relation between home range and dispersal distance. Sample of terrestrial mammals, Urban Region of Besançon

The Eurasian lynx (Lynx lynx) lives mainly in mountain ranges of north-eastern France and some individuals are found in the study area. Its home range is estimated at 20000 hectares (Stahl et al., 2002) and its average dispersal distance is $40 \mathrm{~km}$ (Kramer-Schadt et al., 2004; Zimmermann et al., 2005). The wild cat (Felis silvestris) has a mean dispersal distance of about $30 \mathrm{~km}$ (Stahl and Léger, 1992); the area of its home range is not precisely known but is estimated at about 400 hectares on average (Stahl et al., 1988). The red squirrel (Sciurus vulgaris) represents small mammals with short dispersal distances. It is found in mature 
woodland and intra-urban parks and gardens where it is particularly threatened. Its home range is about 5 hectares (Wauters et al., 1994) and its average dispersal distance about $1 \mathrm{~km}$ (Wauters et al., 2010).
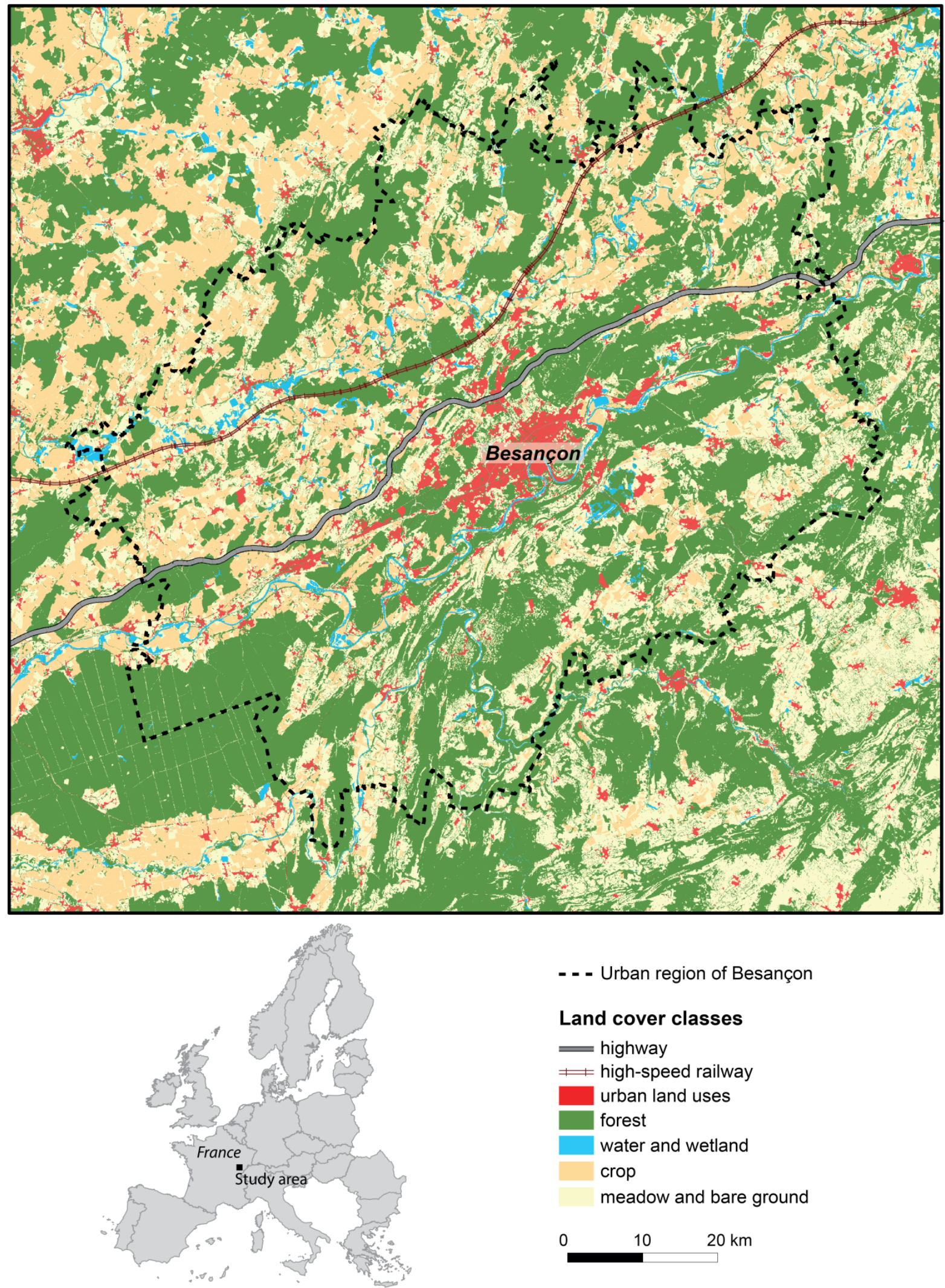

- - - Urban region of Besançon

Land cover classes

= highway

$\Longrightarrow$ high-speed railway

urban land uses

forest

water and wetland

crop

meadow and bare ground

0

$10 \quad 20 \mathrm{~km}$

Figure 2. Initial land cover map of the urban region of Besançon (Eastern France). 


\subsection{Data preparation}

Simulating residential development scenarios and species ecological networks requires the creation of a precise land-cover map. This land-cover map was produced using three sources of vector data to the nearest 1 metre provided by the French cartographical services. BD Topo® IGN 2010 and BD Zones humides (DREAL, 2009) were used to show the road and rail networks, water courses and bodies and wet zones, woodlands and urbanised areas (built areas and associated areas). Agricultural areas were separated into two categories using a data base describing agricultural plots (Registre Parcellaire Graphique, 2010): crops and meadow/bare ground (clearings, fallow land, interstitial farmland). All of these vector data were then combined using GIS software on a 10 m-resolution raster map. The high speed rail line and the motorway were shown by 1 pixel-wide lines to avoid any breaks arising from rasterising the initial vector data (Rothley, 2005). Pixels characterised by urban land use (built areas, car parks, etc.) were dilated/eroded by 5 pixels (50 metres) and grouped into a single 'Urban land uses' land cover class. Lastly, the pixels of road networks superimposed on water areas were extracted into a 'Bridge' class to represent potential crossing points of these structures by animals. In the end, the land-cover map thus composed comprised 5 land cover classes (Figure 2).

Another data set was used to simulate residential development and resulting changes in traffic flows (Table 1).

\begin{tabular}{|c|c|c|}
\hline & Information required & Data sources \\
\hline \multirow[t]{5}{*}{$\begin{array}{l}\text { Simulation of } \\
\text { residential } \\
\text { development }\end{array}$} & $\begin{array}{l}\text { Non developable areas (polygons): } \\
\text { protected natural areas and water } \\
\text { capture areas, steep slopes, water, } \\
\text { flood zones }\end{array}$ & $\begin{array}{l}\text { DREAL, } 2009 \\
\text { BD Topo DEM } ® \text { IGN, } 2010 \\
\text { BD Topo }{ }^{\circ} \text { IGN, } 2010 \\
\text { Cartorisque, MEDDE (http://cartorisque.prim.net/, } \\
\text { accessed August } 2012\end{array}$ \\
\hline & Existing buildings (polygons) & BD Topo® IGN, 2010 \\
\hline & Road and path network (lines) & BD Topo® IGN, 2010 \\
\hline & Retail outlets and facilities (points) & BD SIRENE INSEE 2012 \\
\hline & $\begin{array}{l}\text { Public transport stations (points): } \\
\text { tram and regional trains }\end{array}$ & $\begin{array}{l}\text { Entered manually from plans supplied by } \\
\text { Communauté d'agglomération du Grand Besançon }\end{array}$ \\
\hline \multirow{5}{*}{$\begin{array}{l}\text { Simulation of } \\
\text { traffic on } \\
\text { transport } \\
\text { networks }\end{array}$} & $\begin{array}{l}\text { Sociodemographic data on } \\
\text { individuals, households and } \\
\text { housing }\end{array}$ & INSEE, 2009 population census \\
\hline & Location of economic activities & BD SIRENE INSEE 2012 \\
\hline & Public transport timetables & $\begin{array}{l}\text { Entered manually from bus, tram and regional train } \\
\text { documents provided by transport authorities (Ginko, } \\
\text { SNCF) }\end{array}$ \\
\hline & $\begin{array}{l}\text { Functional characteristics of road } \\
\text { sections (capacity, speed limit, } \\
\text { direction of travel, bends, } \\
\text { gradients) }\end{array}$ & Entered manually and GIS calculations \\
\hline & Road traffic count data & $\begin{array}{l}\text { Direction interdépartementale des routes Centre-Est, } \\
\text { 2013; Conseil Général du Doubs, 2009-2012; } \\
\text { Conseil Général de Haute-Saône, 2008-2012 }\end{array}$ \\
\hline
\end{tabular}

Table 1. Data used to simulate urban changes 


\subsection{Simulation of residential development and associated road traffic scenarios}

\subsubsection{Residential development simulation}

Residential development scenarios are simulated from the existing urban form. As in other studies (e.g. Aguilera et al., 2011; Mitsova et al., 2011; Tannier et al., 2012a), the simulation relates to new residential construction but not to new road building that is often associated with it. New buildings take the form of square cells with sides $20 \mathrm{~m}$ long, which corresponds approximately to the size of a detached house and garden in the study zone. In this, a small collective building is represented by a single cell whereas a large collective building is represented by a group of several contiguous cells. Simulations are made using the MobiSim individual-based simulation platform (Antoni et al. 2011). At the core of this platform, the residential development simulation module is used to simulate the creation of new residential construction and to assign new housing units to those buildings. The procedure for creating new housing units and buildings is a multi-scale procedure.

On the scale of the entire urban region (the macro-geographical scale), the total number of housing units per simulation year is defined. Their distribution is also defined as a function of their type (detached house or flat in a block of flats) and their size expressed by number of rooms.

Then on a meso-geographical scale, a principle for spatial distribution of the housing units created is defined. It is considered that the various built clusters make up the urban region. The built clusters are identified using the Morpholim application (Tannier et al., 2011), integrated for this purpose into MobiSim. They are then categorised by size, the proportion of housing units to be built and their distribution by type for each size class.

On a local (micro-geographical) scale, new buildings are built to accommodate all the previously created housing units. The buildings are located in the cells that are most worth urbanising given a set of planning rules. The first rule ensures that the pattern of cells worth urbanising is fractal and is therefore consistent with the many publications having shown that urban growth engenders fractal built patterns (see for instance Benguigui et al., 2000; Shen 2002; Feng and Chen 2010). The other planning rules introduce additional constraints on residential development. They take account of the proximity of roads, accessibility of shops and services, accessibility to public transport, proximity of open spaces (i.e. non built areas) and the presence of areas that cannot be built on. All these planning rules are integrated into the MUP-City software application (Tannier et al., 2012b). The identification of cells worth urbanising according to MUP-City takes the form of a raster map of potentially building cells, each characterised by the worth of urbanising them. How worthwhile it is for a cell to be urbanised ranges from 0 to 1 .

On this basis, MobiSim constructs buildings by locating them within or close to existing built clusters, in cells worth urbanising according to the map from MUP-City. The buildings are placed first within the built clusters and then, when there are no more building cells within them, at increasing distances from them until all the housing units generated at the outset have been assigned to a building. In this way a map of newly created buildings is obtained for each 
scenario. Each building is characterised by its year of construction, its type (detached house or block of flats) and the number of housing units (differentiated by size) that it holds.

\subsubsection{Simulation of traffic changes}

Within the MobiSim simulation platform, the population changes each year in line with the demographic forecasts for the study zone (Tannier et al., 2015). Some households move and some of them move into the new buildings that have been constructed. This increased population in newly urbanised zones is reflected by increased traffic on the transport networks for everyday trips (work, shopping, leisure, etc.). Rises and even falls in traffic occur in different places depending on the scenario under study. MobiSim includes a simulation model for individual everyday mobility patterns (Antoni and Vuidel, 2010) operating on the basis of a four-stage traffic model. MobiSim does not simulate inter-urban travel but the corresponding traffic, estimated on the basis of road count data, is added to the intra-urban traffic for each road section tallying more than 1000 vehicles per day. This through traffic is increased by $0.2 \%$ on each section of road for each year of simulation in accordance with the continuation of current trends (Commissariat Général au Développement Durable, 2012). This enables us to obtain ultimately the number of vehicles per day in the initial state (in 2010) and in the final state (in 2030) for each section of road in the study area. The present study ignores the possible increase in rail traffic.

\subsubsection{Definition of five scenarios of urban change}

Each residential development scenario consists in applying urbanisation rules on different scales. Global rules of urbanisation determine the overall form of residential development simulated (compact, polycentric, diffuse). Local urbanisation rules are made up of norms about built density and accessibility to shops and services, public transport and open spaces.

Five residential development scenarios have been defined: compact residential development (S1), moderately compact development (S2), controlled development of periurban areas (S3), urban sprawl (S4) and transit-oriented development (S5). These five scenarios represent different possible futures for the growth of residential buildings and associated road traffic in the study zone, given demographic growth and a rising fuel prices estimated by projecting the linear trend from changes observed in recent years.

Residential growth is set at 1400 housing units per year for a 20 year period (2010-2030) by extrapolating linearly the demographic trends from national censuses (INSEE: French National Institute of Statistics and Economic Studies) up to 2030. The annual growth rate of the number of inhabitants was $+0.80 \%$ between 1999 and 2007 whereas it was $+0.37 \%$ between 2007 and 2012 (corresponding to an increase of 900 inhabitants each year). The demographic growth in the study area is thus slowing down. Accordingly, we may imagine an increase of about 800 inhabitants a year in the future. Beside this, the size of households is decreasing and the number of households is increasing. In 1968, the INSEE counts in average three inhabitants per dwelling in the study area but only two inhabitants per dwelling in 2012. The number of dwellings built each year was 1483 between 1968 and 2012. Taking into account both the slower demographic growth and the increase in the number of households, 
we have chosen to simulate the construction of 1400 new dwellings per year. This is in accordance with the recommendation to build 1250 dwellings per year set in the Besançon's SCoT (Territorial Coherence Framework, 2011), whose perimeter is slightly smaller than the perimeter of the study area.

Three types of built clusters have been identified depending on their size: the main built cluster (covering an area of more than $10 \mathrm{~km}^{2}$ ) comprising the city centre and a few outlying districts, medium-sized built clusters $\left(1-10 \mathrm{~km}^{2}\right)$ corresponding to secondary cities and small built clusters $\left(0.2 \mathrm{~km}^{2}-1 \mathrm{~km}^{2}\right)$ corresponding to villages. The lower limit of $0.2 \mathrm{~km}^{2}$ corresponds to the area of the built cluster of the smallest district in the study area. The interbuilding threshold distance for delimiting built clusters, determined using the Morpholim tool, is $260 \mathrm{~m}$. To avoid excessive scattering of new residential developments, the simulated scenarios do not foresee any urbanisation in built clusters of less than $0.2 \mathrm{~km}^{2}$ (hamlets and isolated houses). The distribution of residential growth by size of built clusters varies with the scenarios (Table 2).

In all the scenarios, the number of housing units in each newly constructed building and therefore potentially the population density is higher in the main built cluster (70\% of housing units in collective dwellings) than in medium-sized built clusters (30-50\% of housing units in collective dwellings) and even lower in small built clusters (no collective dwellings).

On the local scale, two fractal dimension intervals were selected for identifying cells worth urbanising: between 1.7 and 1.8 and around 1.5. When the fractal dimension is close to 1.5, built patterns are characterised by high diversity in the size of the built clusters and in the distances between these clusters; conversely a fractal dimension close to 2 characterises uniform built patterns in which buildings may be either scattered or concentrated (Thomas, et al., 2007; Thomas et al., 2008).

\section{Table 2. Quantification of variables for each scenario}

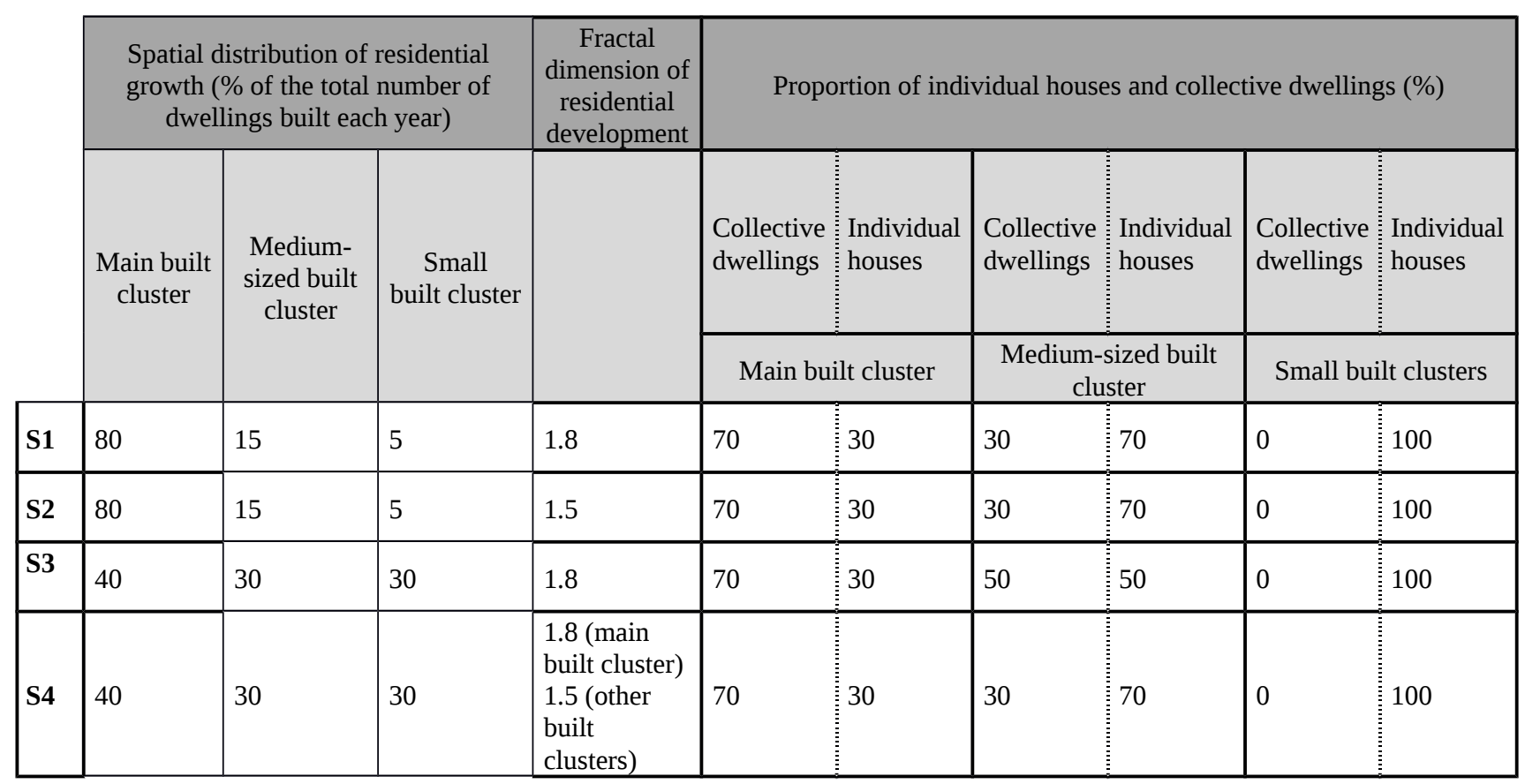




\begin{tabular}{|c|c|c|c|c|c|c|c|c|c|c|}
\hline \multirow{3}{*}{ S5 } & \multirow{2}{*}{$\begin{array}{c}\text { Tram } \\
\text { stations } \\
\text { (buffer } \\
500 \mathrm{~m} \text { ) }\end{array}$} & \multirow{2}{*}{$\begin{array}{l}\text { Main train } \\
\text { stations } \\
\text { (buffer } \\
1000 \mathrm{~m} \text { ) }\end{array}$} & \multirow{2}{*}{$\begin{array}{l}\text { Secondary } \\
\text { train } \\
\text { stations } \\
\text { (buffer } \\
500 \mathrm{~m})\end{array}$} & & \multicolumn{2}{|c|}{$\begin{array}{l}\text { Tram stations } \\
\text { (buffer } 500 \mathrm{~m} \text { ) }\end{array}$} & \multicolumn{2}{|c|}{$\begin{array}{l}\text { Main train stations } \\
\text { (buffer } 1000 \mathrm{~m} \text { ) }\end{array}$} & \multicolumn{2}{|c|}{$\begin{array}{l}\text { Secondary train } \\
\text { stations } \\
\text { (buffer 500m) }\end{array}$} \\
\hline & & & & & \begin{tabular}{|l|}
$\begin{array}{c}\text { Collective } \\
\text { buildings }\end{array}$ \\
\end{tabular} & $\begin{array}{c}\begin{array}{c}\text { Individual } \\
\text { houses }\end{array} \\
\end{array}$ & \begin{tabular}{|l|}
$\begin{array}{c}\text { Collective } \\
\text { buildings }\end{array}$ \\
\end{tabular} & $\begin{array}{c}\begin{array}{c}\text { Individual } \\
\text { houses }\end{array} \\
\end{array}$ & $\begin{array}{l}\text { Collective } \\
\text { buildings } \\
\end{array}$ & \begin{tabular}{|c}
$\begin{array}{c}\text { Individual } \\
\text { houses }\end{array}$ \\
\end{tabular} \\
\hline & 40 & 30 & 30 & $\begin{array}{l}1.8 \text { (main } \\
\text { built cluster) } \\
1.5 \text { (other } \\
\text { built } \\
\text { clusters) }\end{array}$ & 70 & 30 & 50 & 50 & 0 & 100 \\
\hline
\end{tabular}

The importance attributed to the various planning rules in MUP-City varies with the scenarios. In scenarios S1 to S4, greater weight is given to the proximity of shops and services used daily (bakers, grocers, schools, etc.) and to public transport stations (tram, train). Less importance is given to the proximity of the existing road network and to shops and services used weekly (supermarkets, general practitioners, etc.). Proximity to open spaces is of intermediate importance. In scenario S5, proximity to public transport stations outweighs other criteria. Proximity of shops and services used daily is slightly less important. Proximity to the road network, to open spaces and shops and services used weekly is less important still. To quantify the importance of the various rules, MUP-City uses the pairwise comparison method proposed by Saaty (1977) on a scale of importance of 1 to 7 . The values of importance obtained by this method are set out in Table 3.

Table 3. Importance value attributed to the various planning rules

\begin{tabular}{|l|l|l|}
\hline \multirow{2}{*}{ Rule } & \multicolumn{2}{c|}{ Importance value } \\
\cline { 2 - 3 } & Scenarios S1 - S4 & Scenario S5 \\
\hline Proximity to public transport stations & 1.05 & 2.876 \\
\hline Proximity to shops and services used daily & 2.406 & 1.053 \\
\hline Proximity to shops and services used weekly & 0.507 & 0.460 \\
\hline Proximity to existing road network & 0.233 & 0.201 \\
\hline Proximity to open spaces & 0.749 & 0.411 \\
\hline
\end{tabular}

The compact residential development scenario (S1) provides for globally compact and locally dense residential development. Most residential development in the study area occurs in the main built cluster following a monocentric rationale.

The moderately compact development scenario (S2) provides for globally compact and locally moderately dense urbanisation, in line with the idea that moderately dense residential development will be socially more acceptable than very dense development (Camagni et al. 2002). As in S1, most residential development in the study area occurs in the main built cluster.

The controlled development of periurban areas scenario (S3) provides for globally diffuse and locally dense urbanisation. Most residential development in the study area is in small or medium-sized built clusters. The principle behind this scenario is to meet households' demand for detached housing in the countryside while restricting the consumption of space in periurban districts. 
The urban sprawl scenario (S4) provides for globally diffuse residential development that is dense in the main built cluster and moderately dense in the other built clusters. Most residential development in the study area occurs in the small or medium-sized built clusters. This scenario represents the current trend in residential development in the study area.

For the transit-oriented development scenario (S5) (Cervero et al., 2002), 12 new rail stops are added and the frequency of trains is increased so as to improve rail services throughout the study area. Residential development occurs close to the public transport stations, within a perimeter that varies with the type of public transport considered: $500 \mathrm{~m}$ around trams stations (all in the main built cluster), $1000 \mathrm{~m}$ around main line stations (all in medium-sized built clusters) and $500 \mathrm{~m}$ around secondary line stations (all in small built clusters) (El-Geneidy et al., 2014). No residential development occurs in built clusters with no tram or train stations. Bus stops, which can be easily moved, are omitted.

At the end of each simulation, cells belonging to natural or agricultural land-cover classes on the initial land-cover map belong to the urban land-use class.

\subsection{Estimation of the scenarios' ecological impacts}

The impact of each scenario results from the difference between two values of functional connectivity: (1) calculated from the simulated land-cover map and (2) calculated from the initial map. Functional connectivity is quantified from a landscape graph for each given species. For each of the three target species, six landscape graphs were constructed, one for the initial state and one for each scenario, giving a total of 18 landscape graphs. Constructing the graphs involves attributing movement classes to land-cover categories.

\subsubsection{Attribution of movement costs}

Each land-cover class is characterised by its capacity to facilitate or impede movement of the three selected species in the form of movement costs. These costs are used to distinguish different zones within the landscape matrix: suitable, neutral, unfavourable or barrier to movement. Cost values were attributed to land-cover classes on the basis of the literature in the field (Stahl et al., 1988; Wauters et al., 1994; Stahl et al., 2002), but without sufficient information to distinguish between these costs for the three species under consideration (Table 4).

The cost values associated with each section of road vary with the everyday traffic resulting from the simulations. Only road sections with traffic or more than 1000 vehicles per day are assumed to form barriers to animal movement. According to the proposal of Gurrutxaga et al. (2010), such costs are proportional to road traffic and range from 100 (for 1000 vehicles per day) to 900 (for 60000 vehicles per day). 
Table 4. Cost values characterising each land-cover class

\begin{tabular}{lll}
\hline Land-cover class & Ecological function & Cost value \\
\hline High-speed railway & Barrier & 10000 \\
Motorway & Barrier & 10000 \\
\hline Main Road & Unfavourable & {$[100-900]$} \\
\hline Bridge & Suitable & 10 \\
\hline Lake, Pond, River & Barrier & 1000 \\
\hline Urban land use & Unfavourable & 500 \\
Railway & Suitable & 10 \\
\hline Wetland & Barrier & 100 \\
Crop & Neutral & 50 \\
\hline Meadow and bare ground & Suitable & 10 \\
\hline Forest & Favourable to animal movements & 1 \\
\hline
\end{tabular}

\subsubsection{Construction of landscape graphs}

A landscape graph is a set of nodes and links used to model the ecological network of each species. The graph nodes here represent the woodland patches and the connections represent possible movement between patches. Each landscape graph is parameterised in terms of two functional traits of the species in question: its home range and its dispersal distance. The orders of magnitudes of home ranges described in the literature (Stahl et al., 1988; Wauters et al., 1994; Stahl et al., 2002) were used to define the minimum area of habitat patches. This was set at 1 ha for the red squirrel (Sciurus vulgaris), 100 ha for the wild cat (Felis silvestris) and 1000 ha for the Eurasian lynx (Lynx lynx). Forest areas located less than $200 \mathrm{~m}$ from pixels belonging to High-speed railway, Railway, Road, Main road, or Urban land use landcover classes were not included in any habitat patch (Sunde et al., 1998). Forest areas not belonging to a habitat patch were categorized as areas favourable to animal movements. The maximum dispersal distance of each species was used as a threshold for selecting the most likely inter-patch connections. This distance is $1 \mathrm{~km}$ for the red squirrel (Sciurus vulgaris), $30 \mathrm{~km}$ for the wild cat (Felis silvestris) and $40 \mathrm{~km}$ for the Eurasian lynx (Lynx lynx). Landscape graphs for each species were generated using Graphab 1.1. software (Foltête et al., 2012).

\subsubsection{Estimation of functional connectivity of each landscape graph}

Several connectivity metrics can be used to quantify functional connectivity on various scales (Rayfield et al., 2011). In order to compare residential development scenarios, connectivity must be estimated at the global level, i.e. for the entire study area. Among the global metrics, we selected the probability of connectivity index (PC) (Saura and Pascual-Hortal, 2007):

$$
P C=\frac{\sum_{i=1}^{n} \sum^{n} a_{i} a_{j} p_{i j}^{*}}{A^{2}}
$$


where $n$ is the total number of patches, $a_{i}$ and $a_{j}$ the areas of patches $i$ and $j, p_{i j}$ is the maximum probability of potential paths between $i$ and $j$, and $A$ is the total surface are of the study zone. $p_{i j}$ was calculated with an exponential function such that:

$p_{i j}=e^{-k d_{i j}}$

where $d_{i j}$ is the least-cost distance between $i$ and $j$, and $k(0<k<1)$ expresses the intensity of decreasing probability of dispersion resulting from the exponential function.

In order to quantify the loss of connectivity at the scale of each habitat patch, we chose the local metric $\mathrm{PC}_{\text {flux }}$ (Foltête et al., 2014) which is the local contribution of each patch to the global $\mathrm{PC}$ index. For a given patch $j, \mathrm{PC}_{\text {flux }}(j)$ is given by:

$$
P C_{\text {flux }}(j)=\frac{\sum_{i=1}^{n} a_{i} a_{j} p_{i j}^{i}}{A^{2}}
$$

where $n$ is the total number of patches, $a_{i}$ and $a_{j}$ the area of patches $i$ and $j, p_{i j}$ is the maximum probability of potential paths between $i$ and $j$, and $A$ is the total area of the study zone.

The impact of each scenario on the connectivity of the habitat of one species was evaluated by the rate of variation between the initial PC index and the PC index arising from the scenario:

$$
\text { Change rate of } P C \text { index }=\left(P C_{\text {initial }}-P C_{\text {scenario }}\right) \times 100 / P C_{\text {initial }}
$$

The same method was applied for the local $\operatorname{PC}_{\text {flux }}(j)$ metric to measure the loss of landscape connectivity on the scale of each habitat patch $j$.

\section{Results}

For the five residential scenarios, the simulated urbanisation covers a small area. The increase in area belonging to the Urban land use land-cover class represents less than $1 \%$ of the area of the study zone (Table 5).

Table 5. Changes in artificialized areas.

\begin{tabular}{|l|c|c|c|}
\hline & Area of urban land uses $\left(\mathrm{km}^{2}\right)$ & $\begin{array}{c}\text { Change rate } \\
(\%)\end{array}$ & \% study area \\
\hline Initial land cover map & 147.4 & - & 3.91 \\
\hline Scenario 1 & 153.3 & 4.0 & 4.07 \\
\hline Scenario 2 & 154.8 & 5.0 & 4.11 \\
\hline Scenario 3 & 155.9 & 5.8 & 4.14 \\
\hline Scenario 4 & 157.2 & 6.7 & 4.17 \\
\hline Scenario 5 & 157.1 & 6.6 & 4.17 \\
\hline
\end{tabular}


The residential development patterns are realistic and quite distinctive from one scenario to another both locally (Figure 8) and globally (Figure 9).

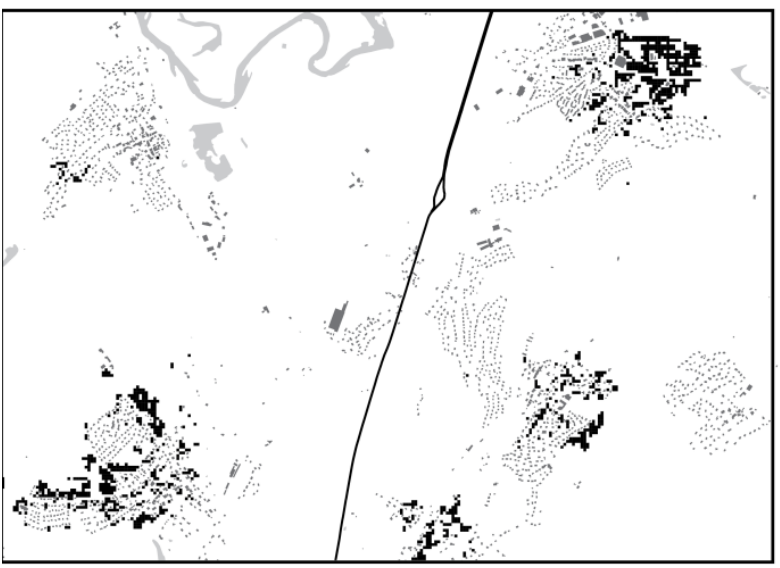

S1 - Compact Residential Development

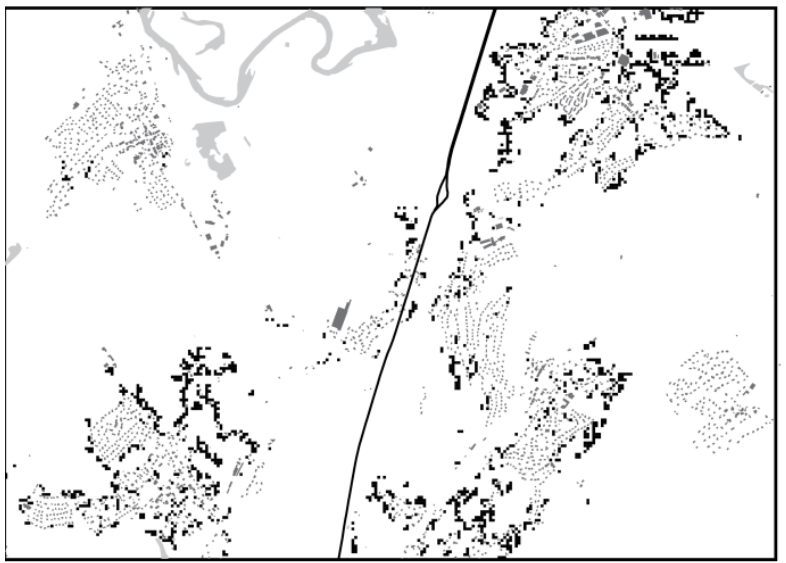

S2 - Moderately Compact Development

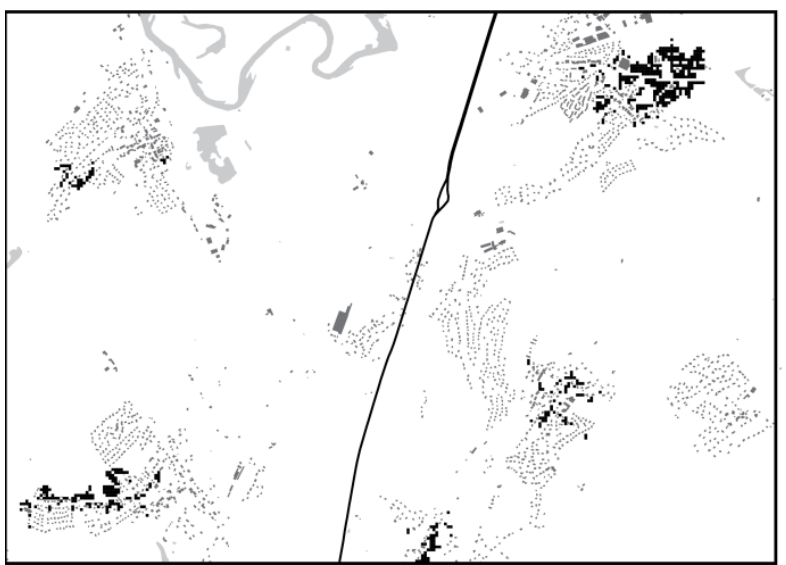

S3 - Controlled Development of Periurban Areas
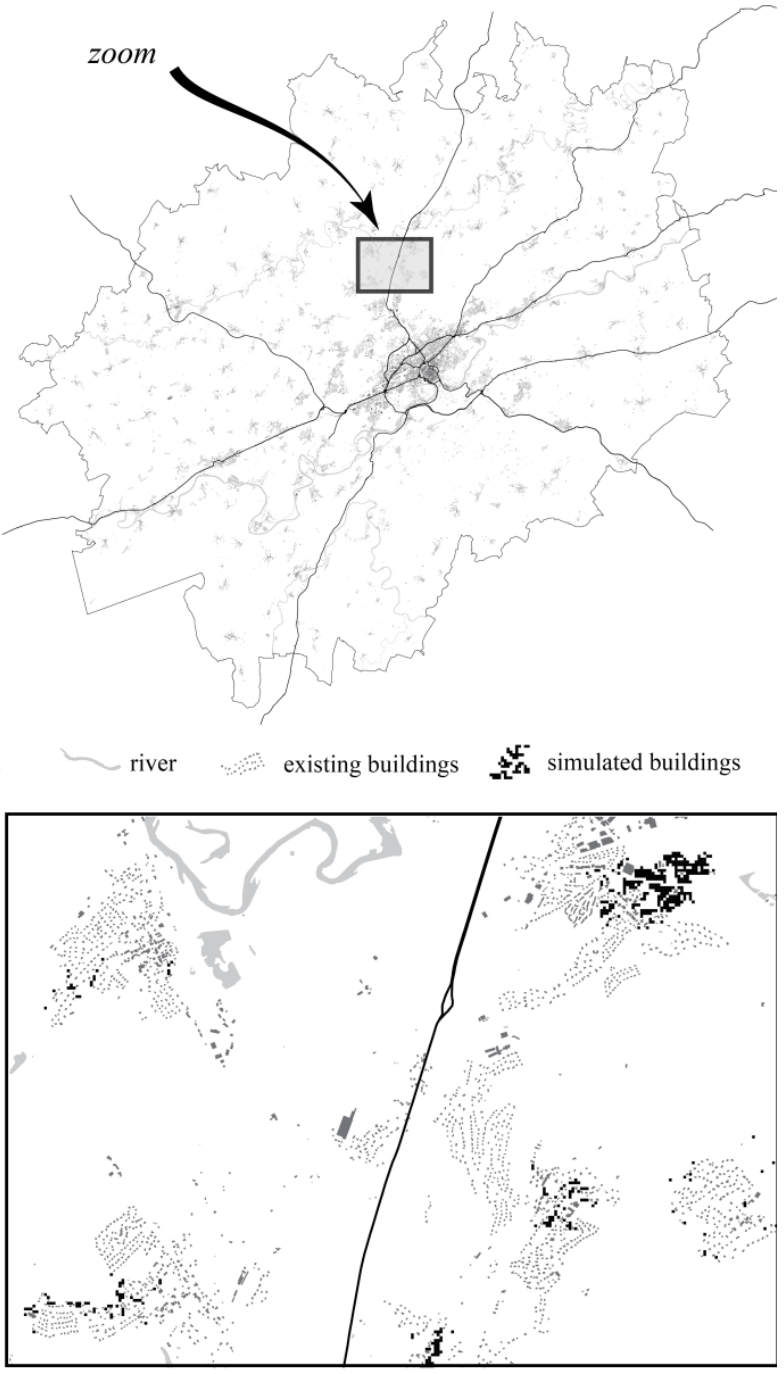

S4 - Urban Sprawl

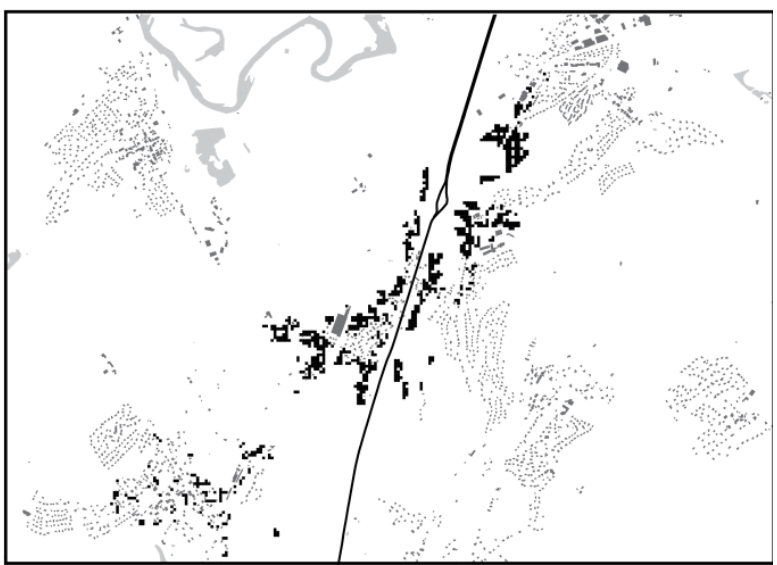

S5 - Transit Oriented Development

Figure 8. Simulated patterns of residential development: detailed maps 

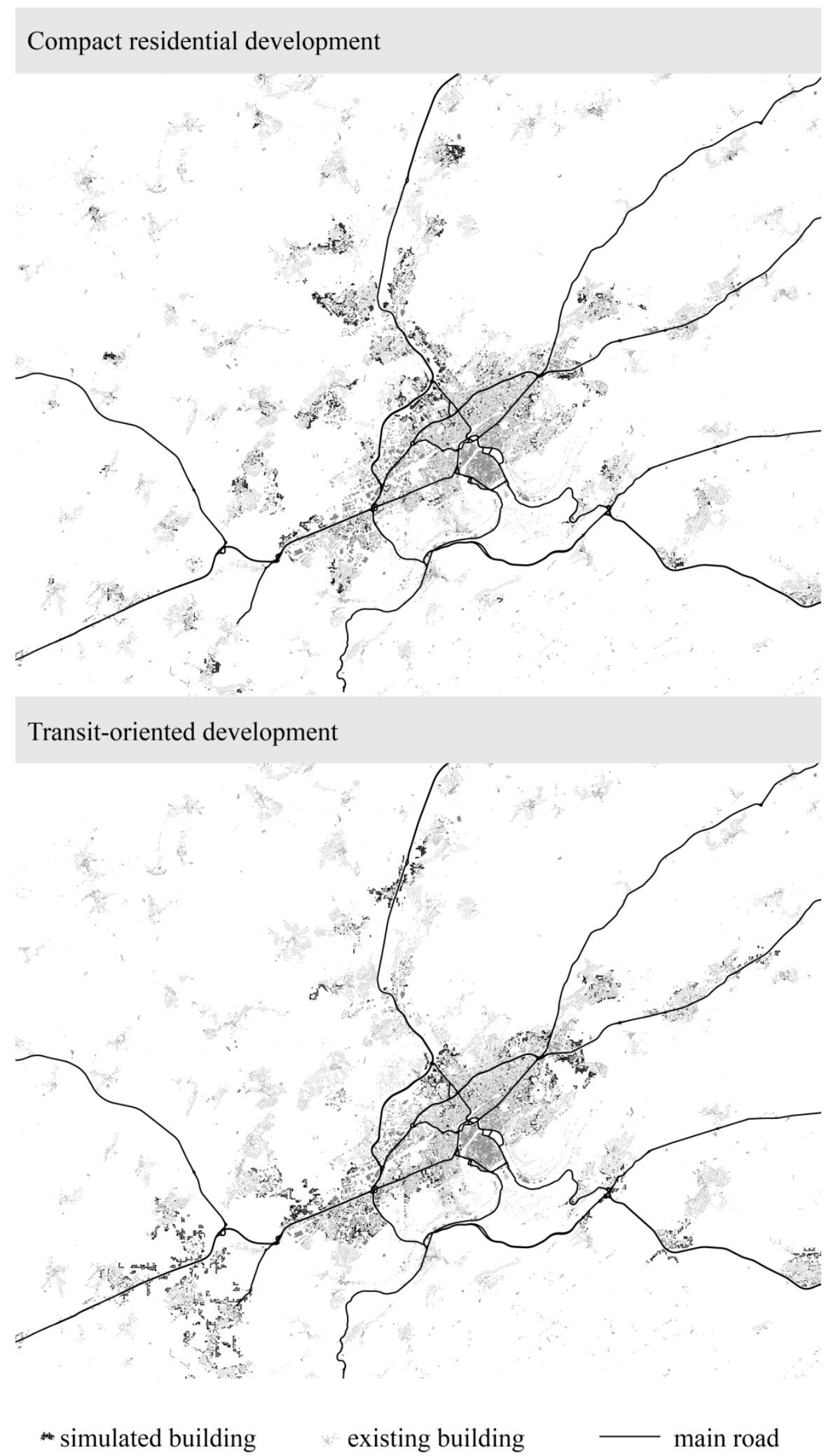

Figure 9. Two examples of the global form of residential development

Table 6 displays changes in road traffic simulated for each scenario. Globally, scenario S3 produces the smallest increase in traffic and scenario S2 the greatest. For all the scenarios, the aggregate number of vehicles per day on all road sections is higher for periurban sections 
(56\% of traffic in 2010 and 55\% in 2030) than intra-urban sections (44\% of traffic in 2010 and $45 \%$ in 2010).

Table 6. Rate of change in aggregate traffic (number of vehicles per day) on road sections for the urban development scenarios, 2010-2030.

\begin{tabular}{|l|r|r|r|r|r|}
\hline & \multicolumn{1}{|c|}{ S1 } & \multicolumn{1}{|c|}{ S2 } & \multicolumn{1}{c|}{ S3 } & \multicolumn{1}{c|}{ S4 } & \multicolumn{1}{c|}{ S5 } \\
\hline Total road sections & 8.4 & 9.8 & 7.6 & 8.4 & 7.8 \\
\hline Intra-urban road sections & 11.1 & 12.5 & 9.7 & 10.2 & 10.7 \\
\hline Periurban road sections & 6.3 & 7.8 & 5.9 & 6.9 & 7 \\
\hline
\end{tabular}

Locally, changes in traffic differ with the roads in question (see Appendix). For a given scenario, some roads record a large rise in traffic others not. The traffic simulated on some roads is sometimes even in decline because of a shift from cars to public transport (e.g.: periurban road 8 in scenario S5, see Appendix). The roads recording the largest rises in traffic vary with the scenarios (e.g.: road J for scenario S5 and road 2 for scenario S2, see Appendix).

Table 7. Habitat areas and areas favourable to animal movements: initial values and change rates for each scenario

\begin{tabular}{|c|c|c|c|c|c|c|c|c|c|}
\hline & \multicolumn{3}{|c|}{ Eurasian Lynx } & \multicolumn{3}{|c|}{ Wild Cat } & \multicolumn{3}{|c|}{ Red Squirrel } \\
\hline & $\begin{array}{l}\text { Area } \\
\left(\mathrm{km}^{2}\right)\end{array}$ & $\begin{array}{l}\text { Change } \\
\text { rate (\%) }\end{array}$ & $\begin{array}{c}\text { \% study } \\
\text { area }\end{array}$ & $\begin{array}{l}\text { Area } \\
\left(\mathrm{km}^{2}\right)\end{array}$ & $\begin{array}{l}\text { Change } \\
\text { rate (\%) }\end{array}$ & $\begin{array}{c}\text { \% study } \\
\text { area }\end{array}$ & $\begin{array}{l}\text { Area } \\
\left(\mathrm{km}^{2}\right)\end{array}$ & $\begin{array}{l}\text { Change } \\
\text { rate (\%) }\end{array}$ & $\begin{array}{c}\% \text { study } \\
\text { area }\end{array}$ \\
\hline \multicolumn{10}{|c|}{ Habitat areas } \\
\hline Initial map & 1064.6 & - & 28.25 & 1413.4 & - & 37.50 & 1751.6 & - & 46.48 \\
\hline S1 & 1064.3 & -0.02 & 28.24 & 1412.9 & -0.03 & 37.49 & 1750.1 & -0.09 & 46.44 \\
\hline S2 & 1063.9 & -0.06 & 28.23 & 1412.3 & -0.08 & 37.47 & 1749.4 & -0.12 & 46.42 \\
\hline S3 & 1064.1 & -0.04 & 28.24 & 1412.5 & -0.06 & 37.48 & 1750.3 & -0.07 & 46.44 \\
\hline S4 & 1062.7 & -0.18 & 28.20 & 1409.9 & -0.25 & 37.41 & 1749.8 & -0.10 & 46.43 \\
\hline S5 & 1047.6 & -1.59 & 27.80 & 1410.0 & -0.24 & 37.41 & 1748.9 & -0.15 & 46.41 \\
\hline \multicolumn{10}{|c|}{ Areas favourable to animal movements } \\
\hline Initial map & 1856.4 & - & 49.26 & 1507.6 & - & 40.00 & 1169.4 & - & 31.03 \\
\hline S1 & 1851.1 & -0.28 & 49.12 & 1502.5 & -0.34 & 39.87 & 1165.4 & -0.34 & 30.92 \\
\hline S2 & 1850.1 & -0.34 & 49.09 & 1501.8 & -0.39 & 39.85 & 1164.6 & -0.41 & 30.90 \\
\hline S3 & 1849.3 & -0.38 & 49.07 & 1500.9 & -0.44 & 39.83 & 1163.1 & -0.54 & 30.86 \\
\hline S4 & 1849.5 & -0.37 & 49.08 & 1502.3 & -0.35 & 39.86 & 1162.4 & -0.60 & 30.84 \\
\hline S5 & 1864.7 & -0.45 & 49.48 & 1502.3 & -0.35 & 39.86 & 1163.4 & -0.52 & 30.87 \\
\hline
\end{tabular}

Table 7 shows that simulated urbanisation is only slightly detrimental to the habitat of the target species and only slightly detrimental to the zones suitable for their movement. The greatest loss of habitat is for the lynx in scenario S5, but this is offset in part by the increase in areas suitable for its movement. The wild cat experiences greater habitat losses than the other species in scenario S4, together with a loss of areas suitable for its movement. For the squirrel, the reduction in areas suitable for its movement is greater in all scenarios than for the other two species. 
Table 8. Values of PC index and change rate for each scenario and each target species. Differentiation of impacts allowing for changes in road traffic alone, residential development alone, or both together.

\begin{tabular}{|c|c|c|c|c|c|}
\hline & & & & change rate & \\
\hline & & PC index & Traffic & $\begin{array}{c}\text { Residential } \\
\text { development }\end{array}$ & Both \\
\hline Eurasian Lynx & Initial & 0.0256 & & & \\
\hline & S1 & 0.0255 & -0.52 & -0.03 & -0.54 \\
\hline & S2 & 0.0255 & -0.52 & -0.07 & -0.59 \\
\hline & S3 & 0.0255 & -0.52 & -0.06 & -0.58 \\
\hline & S4 & 0.0254 & -0.57 & -0.36 & -0.92 \\
\hline & S5 & 0.0247 & -0.57 & -2.98 & -3.56 \\
\hline Wild Cat & Initial & 0.0450 & & & \\
\hline & S1 & 0.0447 & -0.59 & -0.11 & -0.69 \\
\hline & S2 & 0.0446 & -0.60 & -0.23 & -0.82 \\
\hline & S3 & 0.0446 & -0.55 & -0.15 & -0.71 \\
\hline & S4 & 0.0445 & -0.62 & -0.50 & -1.11 \\
\hline & S5 & 0.0445 & -0.59 & -0.63 & -1.22 \\
\hline Red Squirrel & Initial & 0.0265 & & & \\
\hline & S1 & 0.0263 & -0.80 & -0.05 & -0.85 \\
\hline & $\mathrm{S} 2$ & 0.0263 & -0.83 & -0.10 & -0.92 \\
\hline & S3 & 0.0263 & -0.83 & -0.11 & -0.94 \\
\hline & S4 & 0.0262 & -0.90 & -0.16 & -1.07 \\
\hline & S5 & 0.0265 & -0.12 & -0.21 & -0.33 \\
\hline
\end{tabular}

The impact of urbanisation on functional connectivity of habitats varies, though, with the scenario (Table 8). The compact urban scenario (S1) experiences the least impact, followed by the controlled periurban development scenario (S3), then the moderately compact urbanisation scenario (S2), with the latter two differing but slightly. Let us specify here that scenarios S1 and S2 involve an increase in the fractal dimension of residential development. They do not therefore entail a sudden densification of the existing built fabric and maintain intra-urban unbuilt areas. The urban sprawl scenario (S4) leads to even greater impacts, especially on species with higher dispersal characteristics (lynx and wild cat). Lastly the TOD scenario (S5) produces peculiar impact values that are lower for the squirrel but much higher for the lynx.

In general, an increase in traffic contributes more to the loss of functional connectivity than residential development. Only the TOD scenario (S5) entails a greater impact of residential development than changes in traffic on the loss of connectivity of squirrel and lynx habitats.

Besides the global measurement of loss of connectivity arising from each scenario, it is also interesting to analyse the local differentiation of impacts. We present here solely the results for the wild cat (Figure 10). The urban sprawl scenario (S4), which was the one with the greatest impact globally, entails also the greatest reduction in connectivity of the largest habitat patches (i.e. with the highest PC flux values). Conversely, the global PC index suggests that the compact (S1) and moderately compact (S2) urbanisation scenarios have less impact on the wild cat. However, it can be seen here that the controlled urban development scenario (S3) has the least impact on the largest habitat patches. Thus the local measurement of impacts can refine the global measurement. 
Figure 10. Changes in connectivity of each of the habitat patches of the wild cat for each simulated scenario.

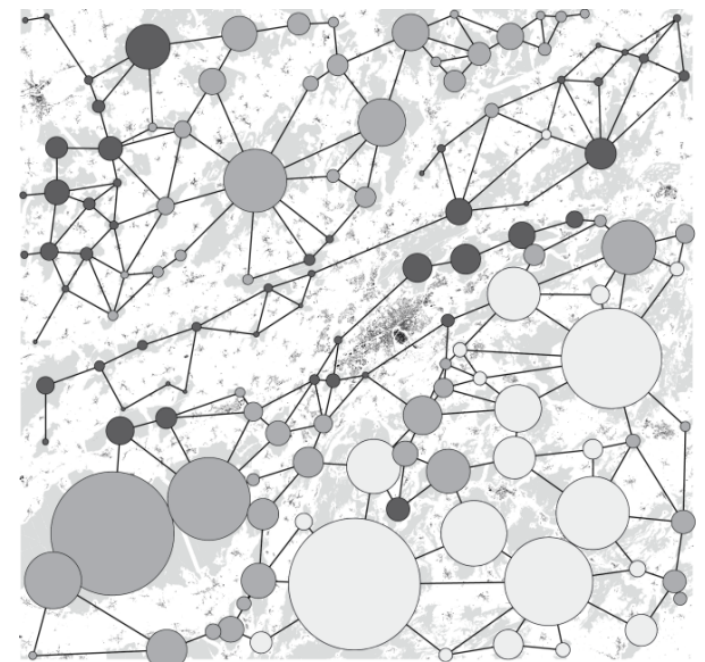

S1 - Compact residential development

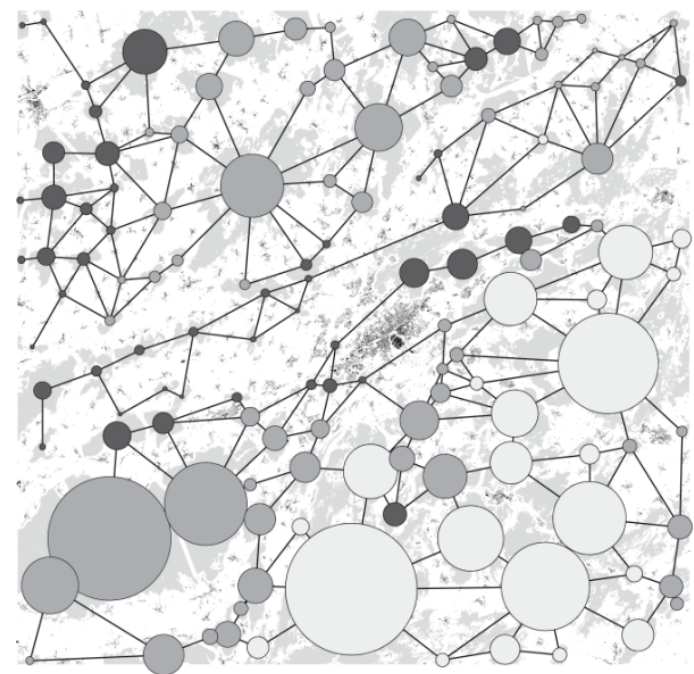

S3 - Controlled development of periurban areas

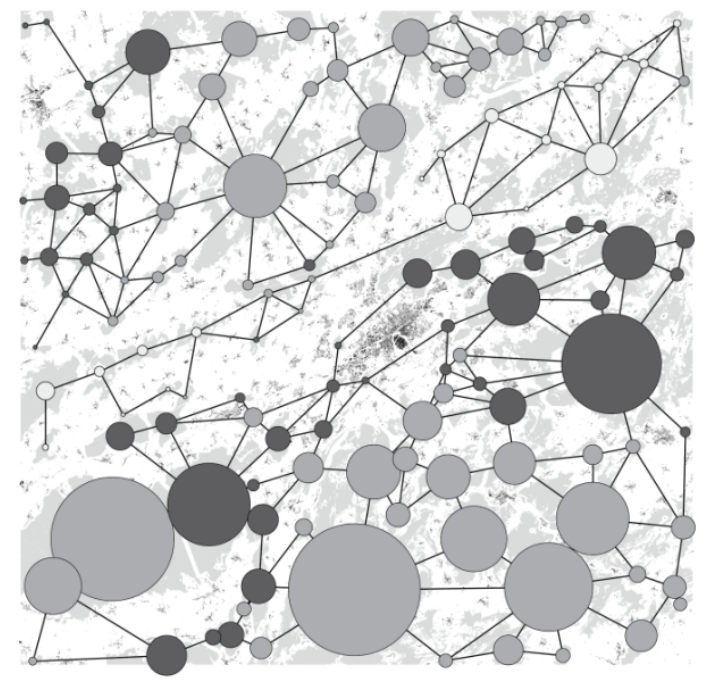

S5 - Transit-oriented development

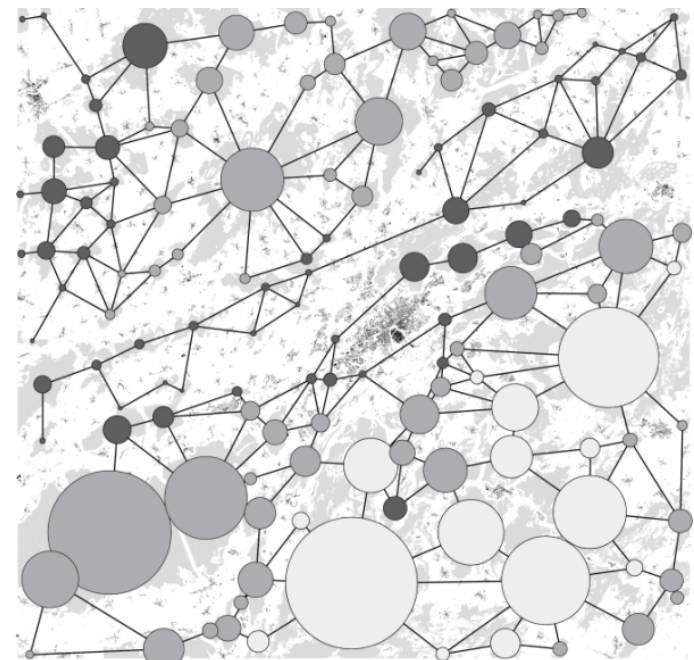

S2 - Moderately compact development

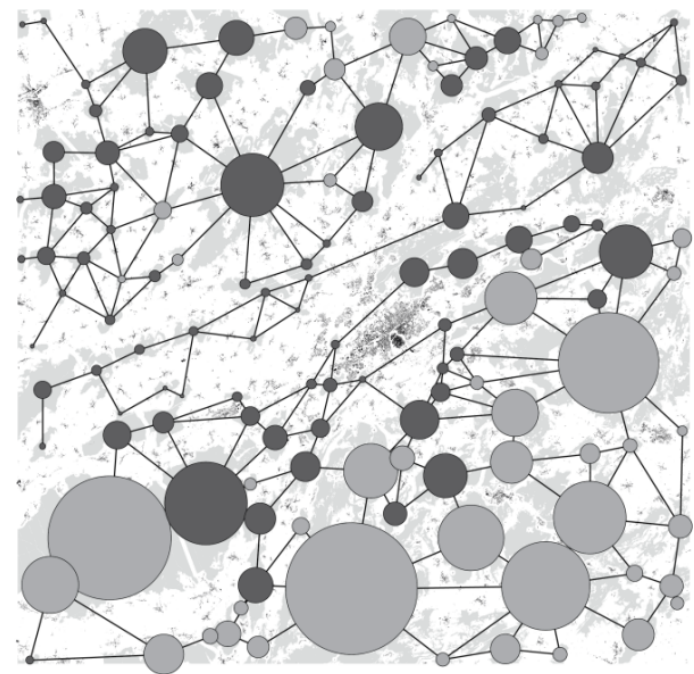

S4 - Urban sprawl

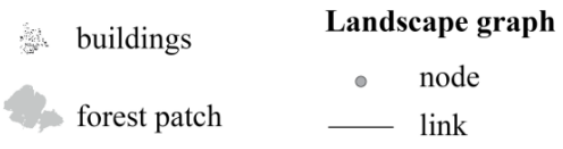

Value of PC Flux

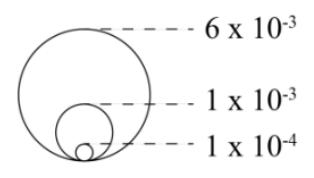

Change rate of PC Flux (\%)

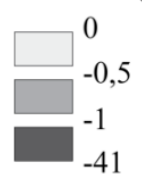

A N

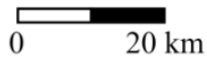


Graph-based connectivity measures may vary according to the definition of landscape-graph elements (i.e. nodes and links). Consequently, it is important to analyse the sensitivity of the connectivity measures to both the cost values set to valuing the links of the graphs and the size of the buffer zone around barriers and unfavourable land uses involved in the definition of the nodes of the graphs.

The cost value assigned to each land-cover class has been initially set by ranking the landcover classes according to their resistance to animal movements. To evaluate the sensitivity of connectivity measures to these cost values, three alternative cost scales have been tested, as suggested by Pereira et al. (2011) (Table 9). For defining these alternative cost scales, the land-cover class Main road has been discretized into four classes according to the amount of traffic on the road. In the "equidistant" cost scale, a distance of 1000 units separates each cost value from the following one. In the "compressed" cost scale, cost values range from 2500 to 7 500. In the "contrasted" cost scale, the difference between low and high cost values is increased compared to the other cost scales. To ensure the comparison of the connectivity measures obtained with each cost scale, the ranking of the land-cover classes according to their resistance to animal movements remains the same for all cost scales.

Table 9. Cost scales used to analyse the sensitivity of connectivity measures to varying cost values

\begin{tabular}{|l|r|r|r|r|}
\hline \multirow{2}{*}{ Land cover class } & \multirow{2}{*}{$\begin{array}{c}\text { Initial cost } \\
\text { scale }\end{array}$} & \multicolumn{3}{|c|}{ Alternative cost scales } \\
\cline { 3 - 5 } & & Equidistant & Compressed & Contrasted \\
\hline Forest & 1 & 1 & 2500 & 1 \\
\hline Meadow and bare ground, railway & 10 & 1000 & 3000 & 100 \\
\hline Crop & 50 & 2000 & 3500 & 200 \\
\hline Wetland & 100 & 3000 & 4000 & 300 \\
\hline Main road 1 & $101-300$ & 4000 & 4500 & 5000 \\
\hline Main road 2 & $301-499$ & 5000 & 5000 & 5000 \\
\hline Urban land use & 500 & 6000 & 5500 & 5000 \\
\hline Main road 3 & $501-700$ & 7000 & 6000 & 5000 \\
\hline Main road 4 & $701-900$ & 8000 & 6500 & 5000 \\
\hline Lake, Pond, River & 1000 & 9000 & 7000 & 9900 \\
\hline Motorway, high-speed railway & 10000 & 10000 & 7500 & 10000 \\
\hline
\end{tabular}

The change rates of PC index resulting from the three alternative cost scales are presented in Table 10. PC change rates are most often lower with the equidistant and compressed cost scales than with the initial cost scale. Contrarily, PC change rates obtained with the contrasted cost scale are identical to those obtained with the initial cost scale. The ranking of the scenarios according to the PC change rates varies little for the lynx and even less for the wild cat. Few differences in the ranking can be observed when two scenarios have very close PC change rates. For the red squirrel, however, the ranking of the scenarios regarding the PC change rates varies according to the cost scale used. This could be explained by the shorter 
size of the links of the squirrel's graph that makes the graph computations more sensitive to the cost scale. We can thus conclude that impact assessments for mammals with medium or long dispersal distances are not sensitive to the cost scale used, while impact assessments for mammals with short dispersal distances are more sensitive to the chosen cost scale.

Table 10. Change rate of PC index for each alternative cost scale, each scenario and each target species.

\begin{tabular}{|c|c|c|c|c|c|}
\hline \multirow{3}{*}{ Species } & \multirow{3}{*}{ Scenarios } & \multirow{3}{*}{$\begin{array}{l}\text { Initial PC } \\
\text { change rate }\end{array}$} & \multicolumn{3}{|c|}{ Alternative cost scales } \\
\hline & & & Equidistant & Compressed & Contrasted \\
\hline & & & PC change rate & PC change rate & PC change rate \\
\hline \multirow{5}{*}{$\begin{array}{l}\text { Eurasian } \\
\text { Lynx }\end{array}$} & S1 & -0.54 & -0.27 & -0.05 & -0.83 \\
\hline & S2 & -0.59 & -0.30 & -0.13 & -0.86 \\
\hline & S3 & -0.58 & -0.31 & -0.04 & -0.88 \\
\hline & S4 & -0.92 & -0.66 & -0.35 & -1.18 \\
\hline & S5 & -3.56 & -2.39 & -3.14 & -2.62 \\
\hline \multirow{5}{*}{ Wild Cat } & S1 & -0.69 & -0.45 & -0.08 & -1.06 \\
\hline & $\mathrm{S} 2$ & -0.82 & -0.54 & -0.18 & -1.15 \\
\hline & S3 & -0.71 & -0.51 & -0.14 & -1.11 \\
\hline & S4 & -1.11 & -1.05 & -0.52 & -1.51 \\
\hline & S5 & -1.22 & -0.78 & -0.73 & -1.45 \\
\hline \multirow{5}{*}{$\begin{array}{l}\text { Red } \\
\text { Squirrel }\end{array}$} & S1 & -0.85 & -0.19 & -0.42 & -0.06 \\
\hline & S2 & -0.92 & -0.26 & -0.57 & -0.09 \\
\hline & S3 & -0.94 & -0.25 & -0.38 & -0.11 \\
\hline & S4 & -1.07 & -0.34 & -0.57 & -0.17 \\
\hline & S5 & -0.33 & -0.42 & -0.39 & -0.21 \\
\hline
\end{tabular}

The second parameter tested was the size of the buffer zone that delimits disturbance areas around pixels belonging to High-speed railway, Railway, Road, Main road and Urban land use land-cover classes. As explained in section 2.5.2, forest areas located less than $200 \mathrm{~m}$ from pixels belonging to those land-cover classes were not included in any habitat patch but were categorized as areas favourable to animal movements. We have tested five changes of this initial $200 \mathrm{~m}$ buffer size: $50 \mathrm{~m}, 100 \mathrm{~m}, 150 \mathrm{~m}, 250 \mathrm{~m}$ and $300 \mathrm{~m}$ (Table 11). Using these alternative buffer sizes, five new graphs have been built for the species with medium dispersal distances only (i.e. the wild cat), and new PC change rates have been calculated. Although little variations in PC change rates can be observed, the ranking of the scenarios is always the same whatever the chosen buffer size. We can therefore conclude that connectivity measures are weakly sensitive to a change in the size of the buffer zone around disturbance areas.

Table 11. Change rate of PC index according to the size of the buffer zone around disturbance areas Species: wild cat

\begin{tabular}{|l|r|r|r|r|r|r|}
\hline \multirow{2}{*}{ Scenarios } & \multicolumn{6}{|c|}{ Size of the buffer zone for defining disturbed areas in forested habitat } \\
\cline { 2 - 7 } & $50 \mathrm{~m}$ & $100 \mathrm{~m}$ & $150 \mathrm{~m}$ & $200 \mathrm{~m}$ (initial) & $250 \mathrm{~m}$ & $300 \mathrm{~m}$ \\
\hline S1 & -0.97 & -0.85 & -0.87 & -0.69 & -0.67 & -0.69 \\
\hline S2 & -1.10 & -0.98 & -0.98 & -0.82 & -0.80 & -0.83 \\
\hline S3 & -1.00 & -0.91 & -0.88 & -0.71 & -0.71 & -0.79 \\
\hline S4 & -1.32 & -1.15 & -1.22 & -1.11 & -1.41 & -1.29 \\
\hline S5 & -1.52 & -1.64 & -1.52 & -1.22 & -1.26 & -1.48 \\
\hline
\end{tabular}




\section{Discussion}

The coupling between urban growth simulation and landscape graphs has been used to compare the potential impacts of five urban development scenarios on the functional connectivity of forest habitats. The results obtained raise several points for discussion.

\subsection{Comparison of scenarios}

The results of simulating residential development and resulting traffic changes show that barrier effects of roads and urbanisation on the connectivity of forest habitats vary with the different scenarios. Globally, the compact city (S1) maintains more functional connectivity for all the species considered whereas urban sprawl (S4) leads to much more marked impacts. Intermediate between the two, scenarios S2 (moderately compact) and S3 (regulated periurban) do not differ greatly from one another.

The TOD scenario (S5) produces specific impact values that are lower for the squirrel and much higher for the lynx. For the lynx, the large reduction in the PC index can be explained in that residential development close to a railway station fragments a large woodland patch, which has a greater impact than simple shrinkage. For this species, the TOD scenario therefore stands apart in that it leads to habitat loss whereas in all other instances the reduction in functional connectivity is mostly due to matrix induration, reflected by a greater reduction of PC than proportion of habitat, as already reported in Tannier et al. (2012a).

It should also be observed that scenario S5 records quite a large rise in periurban traffic, which contradicts the assumptions underpinning transit-oriented development. This unexpected finding may be explained by the configuration of the study area, because the public transport in scenario S5 serves the periurban residential zones well but does not provide ready access to business locations scattered in the city centre. The car therefore remains the preferred means of transport for many periurban residents. However, for this TOD scenario, despite quite a large rise in periurban traffic, residential development impacts the connectivity of squirrel and lynx habitats more than the increase in road traffic does.

\subsection{Differing impacts depending on species}

Earlier research suggested that the impact of urbanisation on functional connectivity declined with the rise in dispersal distance (Fu et al., 2010; Liu et al. 2014; Tannier et al. 2012a). This research does not confirm those findings since we fail to observe regular growth of connectivity (PC index) with increased dispersal distance. Thus the red squirrel, which has the lowest dispersal distance, is more impacted by some scenarios than others. This finding can be explained by our choice to adapt the minimum habitat patch area to the three species in question, to represent their specific home range. This adaptation makes comparison among species more realistic than a single minimum area threshold. At the same time, it considerably changes the connectivity values measured. For example, the sqrPC index (square root of the PC index) calculated for large dispersal distances in our study zone was 0.34 in Tannier et al. (2012a), whereas it is just 0.16 in the present study. 


\subsection{Estimation of impact on connectivity}

Another point worth noting is that the impacts of urbanisation on habitat connectivity are markedly lower than in several earlier studies. The reduction in connectivity is less than $4 \%$ here at the end of 20 years of urban growth. In the same study zone as in the present paper, Tannier et al. (2012a) evaluated this reduction at between 40 and $76 \%$ depending on the scenarios. However, the scenarios implemented are theoretical and the growth rate of built area is very much higher (up to 640\%) than in the present study (between 4 and 6.6\%). In a retrospective study between 1991 and 2006, Liu et al. (2014) report a reduction in connectivity of the order of $90 \%$. Here again, this value can be explained by much greater changes in land cover since forest habitat patches and shrub land occupied respectively $35.2 \%$ and $36.8 \%$ of the area in 1991 whereas they occupied only $18.9 \%$ and $18.1 \%$ of the area in 2006. In a study of the effect of fragmentation on road infrastructures, Fu et al. (2010) also observed large reductions in landscape connectivity based on the PC index: of $26.34 \%$, $27.25 \%, 31.62 \%$ and $45.92 \%$, with $p_{i j}$ of 0.5 for dispersal distances of $12,000 \mathrm{~m}, 8000 \mathrm{~m}$, $4000 \mathrm{~m}$ and $2000 \mathrm{~m}$, respectively. In our zone, we tested the same protocol, by measuring the decline in connectivity between the initial state ignoring the barrier effect of roads and the final state including roads but ignoring the simulated new residential development. By this protocol, the PC index declines on average (for all scenarios) by $-60.8 \%$ for the lynx, $-52.2 \%$ for the wild cat and $-62.3 \%$ for the squirrel, which is more than in Fu et al. (2010).

Thus, the decline in connectivity values observed in this study, which seems very low compared with earlier work, is of the same order of magnitude when compared with the degree of simulated urbanisation.

\subsection{Realistic simulations of urban growth}

Integrated land-use change models (e.g. Mitsova et al., 2011; Puertas et al., 2014; Xi et al., 2012) or urban growth potential models (Kong et al., 2012) simulate the emergence of clusters of cells characterised by the same land cover. Land-use changes (in particular, the conversion of non built cells into built cells) are modelled as a diffusion process in the vicinity of existing built clusters or existing roads. Leapfrogging developments are not numerous, and may even be absent. Our modelling approach creates quite different patterns of urban development. It simulates a fractal dilution of the built density.

The literature in the field mentions that the built density declines as the spatial resolution decreases. This combined decrease is especially marked when the fractal dimension of the built area is low (Tannier et al., 2012b). The reduction in density $\rho_{i}$ observed at a spatial resolution $i$ is related to the density $\rho_{i+1}$ at a lower spatial resolution $i+1$ by the relation:

$$
\frac{\rho_{i+1}}{\rho_{i}}=(r)^{(-2-\mathrm{D})}
$$

where $D$ is the built fractal dimension and $r$ is the reduction factor of the cell size from a given spatial resolution to a lower one (Table 12). 
Table 12. Decrease in the built density according to the fractal dimension $D$ when the size of the elementary spatial unit is reduced by a reduction factor $r$ equal to $1 / 3$.

\begin{tabular}{|c|c|}
\hline $\begin{array}{c}\text { Fractal } \\
\text { dimension } \\
\mathbf{D}\end{array}$ & $\frac{\rho_{i+1}}{\rho_{i}}$ \\
\hline 1.26 & 0.44 \\
\hline 1.46 & 0.55 \\
\hline 1.63 & 0.67 \\
\hline 1.77 & 0.78 \\
\hline
\end{tabular}

In the study area in question, the fractal dimension of the built fabric is low: 1.38 (boxcounting dimension calculated with Fractalyse software - http://www.fractalyse.org/enhome.html). The built density is therefore far lower at fine spatial resolution than at a coarser resolution. Consequently, the fineness of the spatial resolution used for simulating residential development (cell size of $20 \mathrm{~m}$ width; 0.04 ha per grid cell) explains in part why the impact of urban sprawl is relatively low. Changes in land cover and their impact on landscape connectivity would have been quantitatively much larger if a coarser spatial resolution had been adopted. In other studies, such as that of Wei and Zhang (2012) or Vimal et al. (2012), the spatial resolution is $100 \mathrm{~m}$ in width.

\section{Conclusion}

Preserving biodiversity presupposes two types of action: (i) choosing future forms of urbanisation that impact the ecological functionality of organisms' habitats as little as possible and (ii) preventing or limiting the urbanisation of protected areas.

Various authors have tried to allow for these two types of action in studies designed to evaluate the respective value of various urbanisation scenarios in terms of preserving biodiversity. For example, Pentedao (2013) designed eight scenarios by combining four scenarios related to the preservation of open spaces (no preservation, greenway, park system, and network), and two urban development scenarios (compact and dispersed). Bauer and Swallow (2013) proposed an economic model by which to allocate a given conservation budget among multiple habitat patch and dispersal matrix land units. Two land-use intensity parameters indicate the marginal effect of residential development on the size and quality of habitat patches and the inter-patch connectivity. The four conservation policies simulated are: (i) protect $100 \%$ of habitat patches and $0 \%$ of the dispersal matrix, (ii) protect $33 \%$ of habitat patches and dispersal matrix ( 1 acre for every 2 acres that are developed), (iii) protect $50 \%$ of habitat patches and dispersal matrix (1 acre for every 1 acre that is developed), and (iv) protect $50 \%$ of habitat patches and $33 \%$ of dispersal matrix.

In both those papers, the authors ignored the barrier effects of urbanisation due to road and rail traffic. The study by Vimal et al. (2012), which uses a model of land use change to highlight the threat to sites of high conservation interest also ignores the barrier effect of urbanisation due to traffic. In this respect, for our study zone only, our paper shows that the 
decline in functional connectivity of forest habitats is due more to increased traffic than residential development proper, knowing that no new road building was simulated.

Our study shows that certain forms of residential development may entail very different changes in road traffic, especially because of the initial configuration of the study zone. Many authors have shown the fundamental character of interactions between land-use systems and transport systems (including the associated mobility) as two components of the urban system (Wegener 2004; Wegener, 2014). Such interactions are complex and engender non linear effects, which makes it impossible to define simple rules associating one given urban form with a given volume of traffic (Cervero and Murakami, 2010; Conway, 2009; Geurs and van Wee, 2006; Schwanen et al., 2001). Consequently, it is impossible to estimate ex ante the changes in traffic that will result from a given scenario of urban development. This explains the value of integrated models for simulating land use and transport such as MobiSim, which we have used in this study.

In practice, though, few scientific publications present prospective or forecast simulations of urban development combining the simulation of changes in both land-use and traffic. And even fewer publications present such simulation results at a fine spatial resolution. However, in terms of the ecological impact of urbanisation, a sufficiently fine spatial resolution is required to take account of organisms with small home ranges and short dispersal distances.

For the forms of residential development simulated in this article, we had already shown in earlier research that fractal residential development, which allows the preservation of intraurban non built areas, better meets the expectations of the population in terms of open spaces and natural areas than a uniformly dense urban form (Tannier et al., 2012b). This study further suggests that the increase in the fractal dimension of residential development can be useful for preserving habitat connectivity.

In fine, our paper suggests that conservation actions involving the prioritisation of habitat patches cannot be successfully applied everywhere because each study area has its own specific features. Thus the sets of key principles for conservation actions (for a survey, see for instance Crouzeilles et al., 2013) should be put to the test for each study area. To this end, it would seem to be of real interest to simulate scenarios combining the simulation of land-use changes (at fine spatial resolution) and changes in traffic.

\section{Acknowledgements}

This research is part of the Jurassian Arc long-term ecological research site. It has been funded by the European Regional Development Fund (ODIT project, MSHE CN Ledoux, Besançon, France) and by the Regional Council of Franche-Comté (France). Most computations were performed on the supercomputer facilities of the "Mésocentre de Calcul de Franche-Comté". The software applications MUP-City and MobiSim were developed as part of the French PREDIT programme (research programme on innovation in transport), funded by the French Ministry of Ecology, Energy and Sustainable Development. 


\section{References}

Aguilera, F., Valenzuela, L.M., Botequilha-Leitão, A., 2011. Landscape metrics in the analysis of urban land use patterns: A case study in a Spanish metropolitan area. Landsc. Urban Plan. 99, 226-238.

Alberti, M., 2005. The Effects of Urban Patterns on Ecosystem Function. Int. Reg. Sci. Rev. 28, 168-192.

Antoni, J.-P., Tannier, C., Vuidel, G., Hirtzel, J. 2011. MobiSim. Rapport final PREDIT, Groupe Opérationnel $n^{\circ} 6$, Recherche 09MTCV34.

Antoni, J.-P., Vuidel, G., 2010. MobiSim : un modèle multi-agents et multi-scalaire pour simuler les mobilités urbaines. In: J-P. Antoni (Dir.). Modéliser la ville. Forme urbaine et Politiques de transport. Paris, Economica, 50-77.

Bauer, D.M., Swallow S.K., 2013. Conserving metapopulations in human-altered landscapes at the urban-rural fringe. Ecol. Econ. 95, 159-170.

Beardsley, K., Thorne, J.H., Roth, N.E., Gao, S., McCoy, M.C., 2009. Assessing the influence of rapid urban growth and regional policies on biological resources. Landsc. Urban Plan. 93, 172-183.

Benguigui, L., Czamanski, D., Marinov,M., Portugali, Y., 2000. When and Where Is a City Fractal?. Environ. Plan. B Plan. Des. 27, 507-19.

Bierwagen, B.G., 2007. Connectivity in urbanizing landscapes: The importance of habitat configuration, urban area size, and dispersal. Urban Ecosyst. 10, 29-42.

Calabrese, J.M., Fagan, W.F., 2004. A comparison-shopper’s guide to connectivity metrics. Front. Ecol. Environ. 2, 529-536.

Camagni, R., Gibelli, M., Rigamonti, P., 2002. Urban mobility and urban form: the social and environmental costs of different patterns of urban expansion. Ecol. Econ. 40, 199-216

Conway, T., 2009. Local environmental impacts of alternative forms of residential development. Environ. Plan. B Plan. Des. 36, 927-943

Carroll, C., Noss, R.F., Paquet, P.C., 2001. Carnivores As Focal Species For Conservation Planning In The Rocky Mountain Region. Ecol. Appl. 11, 961-980.

Cervero, R., Ferrell, C., Murphy, S., 2002. Transit-Oriented Development and Joint Development in the United States: A Literature Review. TCRP research results digest, 52.

Cervero, R., Murakami, J., 2010. Effects of built environment on vehicle miles traveled: evidence from 370 US urbanized areas. Environ. Plan. B Plan. Des. 42, 400-418

Commissariat Général au Développement Durable, 2012. La circulation routière augmente à un rythme ralenti depuis 2003. Le Point Sur 118, 1-4. 
Conway, T., 2009. Local environmental impacts of alternative forms of residential development. Environ. Plan. B Plan. Des. 36, 927-943.

Crouzeilles, R., Lorini, M.L., Grelle, C.E.V., 2013. The importance of using sustainable use protected areas for functional connectivity. Biol. Cons. 159, 450-457.

Czamanski, D., Benenson, I., Malkinson, D., Marinov, M., Roth, R., Wittenberg, L., 2008. Urban Sprawl and Ecosystems - Can Nature Survive? Int. Rev. Environ. Resour. Econ. 2, 321-366.

Fahrig, L., 1997. Relative Effects Of Habitat Loss And Fragmentation On Population Extinction. J. Wildl. Manage. 61, 603-610.

El-Geneidy, A., Grimsrud, M., Rania, W., Tétreault, P., Surprenant-Legault, J., 2014, New evidence on walking distances to transit stops: identifying redundancies and gaps using variable service areas. Transp. 4, 193-210.

Feng, J., Chen, Y., 2010. Spatiotemporal evolution of urban form and land-use structure in Hangzhou, China: Evidence from fractals. Environ. Plan. B Plan. Des. 37(5), 838-856.

Foltête, J.-C., Clauzel, C., Vuidel, G., 2012. A software tool dedicated to the modelling of landscape networks. Environ. Model. Softw. 38, 316-327.

Foltête, J.-C., Girardet, X., Clauzel, C., 2014. A methodological framework for the use of landscape graphs in land-use planning. Landsc. Urban Plan. 124, 140-150.

Forman, R.T.T., Alexander, L.E., 1998. Roads And Their Major Ecological Effects. Annu. Rev. Ecol. Syst. 29, 207-231.

Fu, W., Liu, S., Degloria, S.D., Dong, S., Beazley, R., 2010. Characterizing the “fragmentation-barrier” effect of road networks on landscape connectivity: A case study in Xishuangbanna, Southwest China. Landsc. Urban Plan. 95, 122-129.

Galpern, P., Manseau, M., Fall, A., 2011. Patch-based graphs of landscape connectivity: A guide to construction, analysis and application for conservation. Biol. Conserv. 144, 44-55.

García-Feced, C., Saura, S., Elena-Rosselló, R., 2011. Improving landscape connectivity in forest districts: A two-stage process for prioritizing agricultural patches for reforestation. For. Ecol. Manage. 261, 154161.

Girardet, X., Foltête, J.-C., Clauzel, C., 2013. Designing a graph-based approach to landscape ecological assessment of linear infrastructures. Environ. Impact Assess. Rev. 42, 10-17.

Geurs, K.T, van Wee, B., 2006. Ex-post evaluation of thirty years of compact urban development in the Netherlands. Urban Stud. 43, 139-160

Gurrutxaga, M., Lozano, P.J., Del Barrio, G., 2010. Assessing Highway Permeability for the Restoration of Landscape Connectivity between Protected Areas in the Basque Country, Northern Spain. Landsc. Res. 35, 529-550.

Hanski, I., 2011. Habitat Loss, the Dynamics of Biodiversity, and a Perspective on Conservation. Ambio 40, 248-255. 
IUCN, 2013. IUCN Red List of Threatened Species. Version 2013.1. [WWW Document]. URL www.iucnredlist.org (accessed 11.5.13).

Kong, F., Yin, H., Nakagoshi, N., James, P., 2012. Simulating urban growth processes incorporating a potential model with spatial metrics. Ecol. Ind. 20, 82-91.

Kramer-Schadt, S., Revilla, E., Wiegand, T., Breitenmoser, U., 2004. Fragmented landscapes , road mortality and patch connectivity : modelling influences on the dispersal of Eurasian lynx. J. Appl. Ecol. 41, 711-723.

Lindenmayer, D.B., Margules, C.R., Botkin, D.B., 2000. Indicators of Biodiversity for Ecologically Sustainable Forest Management. Conserv. Biol. 14, 941-950.

Liu, S., Dong, Y., Deng, L., Liu, Q., Zhao, H., Dong, S., 2014. Forest fragmentation and landscape connectivity change associatedwith road network extension and city expansion: A case study in theLancang River Valley. Ecol. Ind. 36, 160-168.

Marull, J., Mallarach, J.M., 2005. A GIS methodology for assessing ecological connectivity: application to the Barcelona Metropolitan Area. Landsc. Urban Plan. 71, 243-262.

Mörtberg, U.M., Balfors, B., Knol, W.C., 2007. Landscape ecological assessment: a tool for integrating biodiversity issues in strategic environmental assessment and planning. J. Environ. Manage. 82, 45770 .

Minor, E.S., Lookingbill, T.R., 2010. A multiscale network analysis of protected-area connectivity for mammals in the United States. Conserv. Biol. 24, 1549-58.

Mitsova, D., Shuster, W., Wang, X., 2011. A cellular automata model of land cover change to integrate urban growth with open space conservation. Landsc. Urban Plan. 99, 141-153.

Penteado, H.M., 2013. Assessing the effects of applying landscape ecological spatial concepts on future habitat quantity and quality in an urbanizing landscape. Landsc. Ecol. 28, 1909-1921.

Pereira, M., Segurado, P., Neves, M., 2011. Using spatial network structure in landscape management and planning: A case study with pond turtles. Landsc. Urban Plan. 100, 67-76.

Puertas, O.L., Henríque, C., Meza F.J., 2014. Assessing spatial dynamics of urban growth using an integrated land use model. Application in Santiago Metropolitan Area, 2010-2045. Land Use Pol. 38, 415-425.

Rayfield, B., Fortin, M.-J., Fall, A., 2011. Connectivity for conservation: a framework to classify network measures. Ecology 92, 847-858.

Rothley K (2005) Finding and filling the "cracks" in resistance surfaces for least-cost modeling. Ecology and Society 10(1): 4. [online] URL: http://www.ecologyandsociety.org/vol10/iss1/art4/

Saaty, T.L., 1977. A scaling method for priorities in hierarchical structures. J. Math. Psychol. 15, 234-281.

Saura, S., Pascual-Hortal, L., 2007. A new habitat availability index to integrate connectivity in landscape conservation planning: Comparison with existing indices and application to a case study. Landsc. Urban Plan. 83, 91-103.

Schwanen, T., Dieleman, F.M., Dijst, M., 2001. Travel behaviour in Dutch monocentric and polycentric urban systems. J. Transp. Geogr. 9, 173-186. 
Scolozzi, R., Geneletti, D., 2012. A multi-scale qualitative approach to assess the impact of urbanization on natural habitats and their connectivity. Environ. Impact Assess. Rev. 36, 9-22.

Shen, G., 2002. Fractal Dimension and Fractal Growth of Urbanized Areas. Int. J. Geogr. Inf. Sci. 16(5), 437519.

Stahl, P., Artois, M., Aubert, M.F.A., 1988. Organisation spatiale et déplacements des chats forestiers adultes (Felis silvestris, Schreber, 1777) en Lorraine. Rev. d’Ecologie (Terre Vie) 43, 113-132.

Stahl, P., Léger, F., 1992. Le Chat sauvage d’Europe (Felis silvestris Schreber, 1777). Encyclopédie des carnivores de France, Encyclopédie des Carnivores de France. Société Française d’étude et de protection des Mammifères (SFEPM), Nort-sur-Erdre.

Stahl, P., Vandel, J.M., Ruette, S., Coat, L., Coat, Y., Balestra, L., 2002. Factors affecting lynx predation on sheep in the French Jura. J. Appl. Ecol. 39, 204-216.

Syphard, A.D., Clarke, K.C., Franklin, J., 2005. Using a cellular automaton model to forecast the effects of urban growth on habitat pattern in southern California. Ecol. Complex. 2, 185-203.

Tannier, C., Thomas, I., Vuidel, G., Frankhauser, P., 2011. A Fractal Approach to Identifying Urban Boundaries. Geogr. Anal. 43, 211-227.

Tannier, C., Foltête, J.-C., Girardet, X., 2012a. Assessing the capacity of different urban forms to preserve the connectivity of ecological habitats. Landsc. Urban Plan. 105, 128-139.

Tannier, C., Vuidel, G., Houot, H., Frankhauser, P., 2012b. Spatial accessibility to amenities in fractal and nonfractal urban patterns. Environ. Plan. B Plan. Des. 39, 801-819.

Tannier, C., Hirtzel, J., Stephenson, R., Couillet, A., Vuidel, G., Youssoufi, S., 2015. Conception and use of an individual-based model of residential choice in a planning decision process. Feedback from an experimental trial in the city of Besançon, France, Progress in Planning, DOI:

10.1016/j.progress.2015.04.001

Taylor, P.D., Fahrig, L., With, K.., 2006. Landscape connectivity: A return to basics, in: Crooks, K.R., Sanjayan, M. (Eds.), Connectivity Conservation. Cambridge University Press, Cambridge, UK, pp. 29-43.

Urban, D., Keitt, T., 2001. Landscape Connectivity : A Graph-Theoretic Perspective. Ecology 82, 1205-1218.

Urban, D.L., Minor, E.S., Treml, E. a, Schick, R.S., 2009. Graph models of habitat mosaics. Ecol. Lett. 12, 26073.

Vimaln R., Geniaux, G., Pluvinet, P., Napoleone, C., Lepart, J., 2012. Detecting threatened biodiversity by urbanization at regional and local scales using an urban sprawl simulation approach: Application on the French Mediterranean region. Landsc. Urban Plan. 104, 343- 355.

Wei, Y., Zhang, Z., 2012. Assessing the fragmentation of construction land in urban areas: An index method and case study in Shunde, China. Land Use Pol. 29, 417- 428.

Wauters, L., Casale, P., Dhondt, A.A., 1994. Space use and dispersal of red squirrels in fragmented habitats. Oikos 69, 140-146. 
Wauters, L.A., Verbeylen, G., Preatoni, D., Martinoli, A., Matthysen, E., 2010. Dispersal and habitat cuing of Eurasian red squirrels in fragmented habitats. Popul. Ecol. 52, 527-536.

Wegener, M., 2004. Overview of land-use transport models. In: Hensher D.A., Button K., Handbook in transport, 9, Transport geography and spatial systems, Pergamon-Elsevier, 127-146.

Wegener, M. (2014). Land-use transport interaction models. In: Fischer, M. M., Nijkamp, P., (eds) : Handbook of Regional Science. Springer, 742-758.

Xi, F., He, H.S., Clarke K.C., Hu, Y., Wu, X., Liu, M., Shi, T., Geng, Y., Gao, C., 2012. The potential impacts of sprawl on farmland in Northeast China_Evaluating a new strategy for rural development. Landsc. Urban Plan. 104, 34-46.

Zetterberg, A., Mörtberg, U.M., Balfors, B., 2010. Making graph theory operational for landscape ecological assessments, planning, and design. Landsc. Urban Plan. 95, 181-191.

Zimmermann, F., Breitenmoser-Würsten, C., Breitenmoser, U., 2005. Natal dispersal of Eurasian lynx (Lynx lynx) in Switzerland. J. Zool. 267, 381. 


\section{Appendix. Detailed results of traffic simulations}

Main roads in the study area (city of Besançon and its urban region).

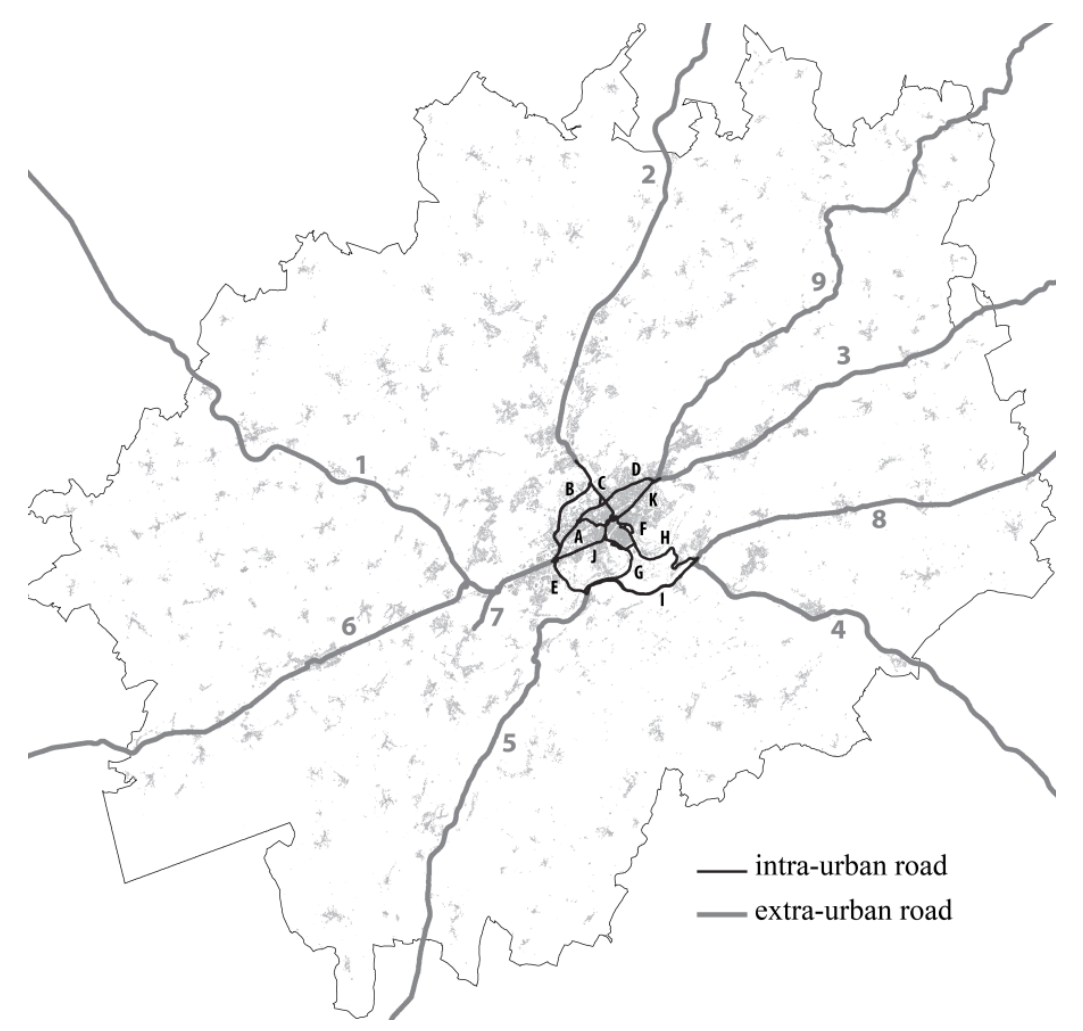

Number of vehicles per day on the main roads - Average number of vehicles per day for all sections of each road

\begin{tabular}{|c|c|c|c|c|c|c|c|}
\hline & Road code & Initial situation & $\mathrm{S} 1$ & $\mathrm{~S} 2$ & S3 & S4 & S5 \\
\hline \multirow[t]{11}{*}{ Intra-urban roads } & A & 15467 & 16878 & 17004 & 17018 & 16978 & 16480 \\
\hline & B & 35074 & 38839 & 39216 & 37119 & 37126 & 37266 \\
\hline & $\mathrm{C}$ & 22075 & 25210 & 25184 & 23755 & 23677 & 23603 \\
\hline & $\mathrm{D}$ & 19874 & 21699 & 22002 & 21685 & 21607 & 22070 \\
\hline & E & 29978 & 32279 & 32591 & 31939 & 32214 & 32229 \\
\hline & $\mathrm{F}$ & 17019 & 18333 & 18426 & 18284 & 18270 & 18311 \\
\hline & G & 14524 & 15851 & 15762 & 15514 & 15992 & 15929 \\
\hline & $\mathrm{H}$ & 15946 & 16541 & 16896 & 16666 & 16757 & 16998 \\
\hline & I & 14318 & 15171 & 15529 & 15352 & 15412 & 15537 \\
\hline & $\mathrm{J}$ & 19799 & 21789 & 21954 & 22069 & 22536 & 22816 \\
\hline & 1 & 8810 & 8969 & 8955 & 9377 & 9271 & 9176 \\
\hline \multirow[t]{8}{*}{ Extra-urban roads } & 2 & 18192 & 20608 & 21844 & 19266 & 19189 & 19528 \\
\hline & 3 & 12363 & 12899 & 13034 & 12956 & 13066 & 13331 \\
\hline & 4 & 22473 & 23568 & 23578 & 23695 & 23933 & 23916 \\
\hline & 5 & 9728 & 9772 & 9691 & 9601 & 9834 & 9969 \\
\hline & 6 & 20202 & 21395 & 21496 & 21501 & 22028 & 22174 \\
\hline & 7 & 6077 & 6389 & 6287 & 6867 & 6930 & 7716 \\
\hline & 8 & 4062 & 4026 & 4118 & 4244 & 4086 & 3948 \\
\hline & 9 & 3926 & 4114 & 4195 & 4175 & 4331 & 4155 \\
\hline
\end{tabular}


